\title{
Shareholder Litigation Risk and Managers' Private Disclosure of Earnings Warnings
}

\begin{abstract}
This paper examines managers' use of a private disclosure channel to provide early earnings warnings and therefore reduce bad news shocks around public announcements. I ask whether firms are more likely to provide private earnings warnings to analysts when expected shareholder litigation risk increases. To identify private communication, I measure variation in firms' propensity to privately disclose earnings warnings using the difference between analysts' and a selected group of benchmark forecasters' revisions of short-term earnings forecasts around earnings announcements. Using plausibly exogenous variation in expected shareholder litigation risk based on judge ideology, I find that managers are more likely to leak bad news privately when shareholder litigation risk increases. This effect is concentrated among large firms that are more likely the target of shareholder lawsuits. I conclude that firms react to the legal system by disclosing private earnings warnings to ensure stock prices incorporate this information in a timely manner.
\end{abstract}

Keywords: Litigation risk, private disclosure, private communication, sell-side analysts

JEL Classifications: D82, K41, M41. 


\section{Introduction}

The extant theoretical and empirical literature on disclosure (e.g., Beyer et al. [2010a]) is largely based on the premise that firms can choose to withhold private information or use public voluntary disclosure to reveal this information. Yet, firms can also choose to privately disclose information to selected market participants to indirectly influence market prices, such as through private communication with sell-side analysts (e.g., Ajinkya and Gift [1984]; King et al. [1990]; Versano and Trueman [2017]). ${ }^{1}$ While some prior studies have explored firms' use of private communication with selected large investors and analysts (e.g., Green et al. [2014]; Bushee et al. [2018]), private communication as an alternative voluntary disclosure channel remains relatively unexplored.

In this paper, I examine firms' use of a private disclosure channel in the context of expected shareholder litigation risk, which is one of the key motives for voluntary disclosure (e.g., Skinner [1994]; Healy and Palepu [2001]). I broadly define voluntary disclosure as managers' dissemination of pieces of information to ensure stock prices incorporate this information in a timely manner, and examine whether managers are more likely to disclose earnings warnings privately to analysts when the threat of shareholder litigation increases. My primary argument is that because analysts' revisions of earnings forecasts trigger changes in stock prices (e.g., Gleason and Lee [2003]), private communication with analysts can be an effective strategy to indirectly adjust market expectations (e.g., Ajinkya and Gift [1984]) and avoid potentially costly shareholder litigation associated with negative information shocks around public information events.

In fact, firms have incentives to reduce the occurrence of shareholder lawsuits which are based on claims that firms have provided misleading statements or omitted material pieces of information under the securities law (e.g., Billings et al. [2021]). Because securities class action lawsuits are typically triggered by unexpected stock price drops (e.g., Langevoort

\footnotetext{
${ }^{1}$ Throughout the paper, I use the shorthand "analysts" to refer to sell-side analysts employed at brokerage houses, unless specifically noted otherwise.
} 
[2009]; Levine [2014]; LaCroix [2020]), firms have incentives to "leak" bad news quickly to reduce the threat of shareholder litigation and reputation damages (e.g., Skinner [1994]; Kasznik and Lev [1995]). While firms can report bad news publicly, I argue that the private disclosure of earnings warnings through analysts is a viable alternative, and potentially less costly, channel for managers to reduce the impact of bad news shocks.

Managers' private communication with analysts is prevalent even though Regulation Fair Disclosure (henceforth, "Reg FD") prohibits the communication of material private information between firms and market participants (e.g., Green et al. [2014]; Soltes [2014]; Brown et al. [2015]; Solomon and Soltes [2015]; Bushee et al. [2017, 2018]; Campbell et al. [2021]). Under Reg FD, firms are still allowed to provide pieces of non-material information that can be combined to a material mosaic, emphasize public information, corroborate analysts' private signals (Solomon and Soltes [2015]), and review their models (SEC [2010]). In addition, the literature suggests Securities and Exchange Commission ("SEC") enforcement actions have been insufficient in deterring managers' selective disclosure of information (e.g., Solomon [2005]; Bengtzen [2017]). Because firms have the opportunity to communicate non-material pieces of information (Solomon and Soltes [2015]) and the risk of Reg FD enforcement is low (Allee et al. [2020]), firms have incentives to privately disclose information through analysts to leak information to market participants.

To identify potential private communication, I construct a novel measure of variation in firms' propensity to privately disclose short-term earnings warnings to analysts based on analysts' revisions of short-term earnings forecasts around earnings releases. The choice to focus on analysts' forecast revisions rests on the widespread manager-analyst private communication post-Reg FD (e.g., Soltes [2014]), analyst reliance on private conversations with managers to update their forecasts (e.g., Brown et al. [2015]), and the evidence that analysts' forecast revisions are priced by the market (e.g., Stickel [1989]; Gleason and Lee [2003]). Based on these pillars, I argue that firms' private disclosure of information can indirectly influence market prices and therefore reduce the risk of stock price shocks around public in- 
formation events such as public voluntary disclosures or scheduled earnings announcements.

A key feature of my research design is that I compare the forecast revisions of analysts to those of a group of benchmark forecasters assumed not to receive private information from managers. Doing so is important because firms' private interactions with analysts typically concentrate around earnings announcements (Soltes [2014]) and analysts respond to a wealth of other public signals around earnings announcements (e.g., Abarbanell [1991]; Clement et al. [2011]). I argue that the selected group of benchmark forecasters responds similarly to the public information in earnings releases, but without having access to firms' private information. By benchmarking against a control group, I can therefore hold constant analysts' revisions due to public information and better capture variation in the likelihood that analysts receive private signals from managers. To construct a control group of benchmark forecasters, I use contributors on Estimize, a crowdsourced financial forecasting platform, which prior research has shown provides useful information to the capital market (e.g., Jame et al. [2016]).

Using a firm-quarter sample from 2012-2019 with coverage from I/B/E/S analysts and Estimize benchmark forecasters, I first document a clear difference in forecasting behavior for these groups. Around earnings announcements, analysts systematically revise their quarterly earnings forecasts downwards, but benchmark forecasters do not lower their estimates as much: while the control group's mean forecast revisions are -0.49 cents, analysts' mean forecast revisions are -2.80 cents. Accordingly, I argue that analysts' incremental forecast revision (-2.35 cents) is associated with managers' private disclosure of information to analysts. That is, relative to the control group, I assume my measure suggests that analysts who revise earnings forecasts more negatively (positively) are more likely to receive bad (good) news from managers. Because my study focuses on managers' use of private earnings warnings in the face of shareholder litigation risk, I empirically focus on situations when firms are more likely to leak bad news privately to analysts.

I validate my measure of private communication as follows. The first validation test 
relies on prior research that suggests private access to managers varies predictably across analysts, as analysts issuing positive stock recommendations are more likely to receive inside information than those issuing negative stock recommendations. (e.g., Chen and Jiang [2006]; Mayew [2008]). If my measure captures variation in the probability that analysts receive private earnings warnings from managers, I expect analysts holding a favorable view of the firm are more likely to receive information than those holding an unfavorable view. Using an analyst-firm-quarter sample, I confirm that the probability of receiving bad news is positively associated with the favorability of analysts' outstanding stock recommendations.

An additional potential source of variation in my empirical measure is based on analysts' (but not benchmark forecasters') incentives to please managers with pessimistic earnings forecasts and help firms meet the consensus forecast (e.g., Richardson et al. [2004]; Ke and $\mathrm{Yu}$ [2006]). To rule out this possibility, I present a second validation test. I argue that if my measure indeed captures variation in managers' propensity to privately leak bad news to analysts, it should be associated with future adverse news. I find that my measure is positively associated with the probability that firms report a loss, miss next-quarter earnings expectations, and report a decrease in quarterly earnings. These results further validate my empirical measurement.

I next test the hypothesis that an increase in shareholder litigation risk increases firms' propensity to privately leak bad news to analysts. I rely on Huang et al.'s [2019] measure of ex-ante shareholder litigation risk, which exploits plausibly exogenous variation in the appointment of federal judges and captures the extent to which judges take a pro-shareholder versus pro-firm standpoint. Empirically, shareholder litigation risk is estimated by the probability that a panel of three randomly selected judges in a given circuit is dominated by liberal judges, i.e., judges who are more likely to decide in favor of shareholders rather than the firm. I estimate the relation between shareholder litigation risk and firms' propensity to provide private earnings warnings while including circuit and year-quarter fixed effects in the regressions to control for unobservable factors that vary across circuits, macroeconomic 
trends, changes in the political landscape, and trends in securities class action filings over time.

I find that managers are more likely to provide private earnings warnings to analysts when shareholder litigation risk increases. This result is consistent with theory and empirical evidence in prior research that managers increase the public disclosure of bad news information to reduce expected shareholder litigation (e.g., Skinner [1994]). Importantly, this result is found after controlling for firms' public voluntary disclosure of information. In addition, I find the effect is concentrated among large firms that are more frequently the target of securities class action lawsuits and hence have stronger incentives to leak bad news when shareholder litigation risk increases (e.g., Francis et al. [1994]; Correia and Klausner [2012]; Huang et al. [2019]; LaCroix [2020]).

This study contributes to the literature on managers' disclosure choices in response to shareholder litigation risk. Prior research has largely addressed firms' decision to withhold information or publicly disclose (e.g., Skinner [1994]; Kasznik and Lev [1995]; Johnson et al. [2001]; Field et al. [2005]; Rogers and Van Buskirk [2009]; Chen et al. [2011]; Houston et al. [2019]; Huang et al. [2020]). While early research suggests that private disclosure through market participants, such as analysts, can be an effective strategy to indirectly adjust market expectations and valuations (e.g., Ajinkya and Gift [1984]; King et al. [1990]), gaps remain in our understanding about whether and when managers use private communication as a disclosure channel. The idea that managers engage in private communication with analysts to reduce the threat of shareholder litigation has not been examined in prior research.

My study relates to the prior literature that finds evidence consistent with Skinner's [1994] initial result that firms disclose bad news in the face of shareholder litigation risk. For example, using plausibly exogenous variation in expected shareholder litigation risk based on judge ideology, Huang et al. [2019] find that firms increase their bad news pre-disclosures before earnings releases. Also, Billings et al. [2021] study firms' disclosure decisions following litigation and find that the increased supply of public information helps firms adjust analysts' 
expectations. My study provides important incremental insights beyond these prior studies, by finding evidence on firms' use of private disclosure through analysts as a channel to lower market expectations and reduce shareholder legal actions.

My study relates to Matsumoto [2002], who examines the association between an industry measure of litigation risk and the likelihood that firms manage analyst expectations to avoid negative earnings surprises. Similar to Matsumoto [2002], I examine firms' use of private communication with analysts to reduce shareholder litigation risk. Empirically, Matsumoto [2002] does not find evidence consistent with a relation between litigation risk and firms' use of expectations management to reduce analysts' forecasts. Using an alternative measure to capture variation in firms' propensity to leak information privately to analysts and a more precise measure of ex-ante litigation risk (Huang et al. [2019]), I do find evidence consistent with a link between firms' perceived litigation risk and their private disclosure of information. Moreover, I demonstrate that my measure captures a different construct than Matsumoto's [2002] measure of expectations management, as my measure is negatively associated with the likelihood that firms report earnings that meet or beat expectations.

This study also contributes to the nascent literature on managers' private communication with selected market participants (e.g., Green et al. [2014]; Soltes [2014]; Brown et al. [2015]; Solomon and Soltes [2015]; Bushee et al. [2017, 2018]; Allee et al. [2020]; Johnson et al. [2020]; Campbell et al. [2021]). Based on prior evidence that managers perceive a low risk of Reg FD enforcement (Allee et al. [2020]) and enjoy flexibility in communicating non-material pieces of information to selected groups (Solomon and Soltes [2015]), I exploit a unique setting to study managers' private communication. By benchmarking against a control group that is assumed to only observe public information disclosures, I can empirically capture variation in the likelihood that analysts revise their forecasts due to managers' private communication and therefore measure variation in managers' propensity to leak information to analysts. The results suggest that private communication can be a viable alternative disclosure strategy that can lower the risk of costly securities class action lawsuits. 


\section{Background, research question, and hypothesis}

\subsection{Public communication and the risk of shareholder litigation}

Federal securities class action lawsuits are filed by shareholders who suffered economic losses due to firms' violations of the securities law. Most claims are filed under Rule 10b-5 of the 1934 Exchange Act, on which basis plaintiffs must prove that the economic losses associated with the buying and selling of the security are due to firms' misrepresentation or omission of material information (Aganin [2021]). ${ }^{2}$ As the court case Halliburton Co. $v$. Erica P. John Fund, Inc. highlighted, shareholders can rely on the integrity of the market in which prices reflect all available information to make claims. Consequently, lawsuits are filed because of large stock price drops, on which basis plaintiffs argue that firms have intentionally withheld bad news (e.g., Skinner [1994, 1997]; Francis et al. [1994]; Levine [2014]). ${ }^{3}$ To reduce the expected costs associated with shareholder litigation, managers have incentives to disclose bad news quickly (Healy and Palepu [2001]). ${ }^{4}$

Empirical evidence is consistent with this hypothesis. Skinner [1994] documents an increase in voluntary disclosures when firms report bad news rather than good news. By disclosing timely earnings warnings, managers can reduce the probability of shareholder lawsuits and avoid a stock price penalty from reporting bad earnings news. Similarly, Kasznik and Lev [1995] explore firms' voluntary disclosure preceding large earnings surprises and find that managers increase pre-disclosures to avoid disappointing the market with bad news shocks. ${ }^{5}$ Recent research using plausibly exogenous variation in shareholder litigation risk

\footnotetext{
${ }^{2}$ Shareholders can also file class action lawsuits or derivative lawsuits on the state level. But, in today's judiciary system, federal-level lawsuits have become the means for shareholders to make claims (Thompson and Sale [2003]). Even merger and acquisition filings and claims under Section 11 of the 1933 Exchange Act are shifted from state- to federal-level courts (Aganin [2021]).

${ }^{3}$ This goes back to the Supreme Court ruling on Basic Inc. v. Levinson in 1988 and subsequently led to a multi-billion dollar industry for plaintiff law firms (Langevoort [2009]).

${ }^{4}$ Firms are also motivated to reduce forward-looking information when they fear investors punish them for poor forecasts (Healy and Palepu [2001]). However, this study examines managers' response to shareholder litigation risk in the short term rather than the long term relative to current-quarter earnings releases.

${ }^{5}$ Also, Field et al. [2005] find a positive association between litigation risk and earnings warnings. Cao and Narayanamoorthy [2011] report an increase of bad news disclosure and a decrease of good news disclosure when litigation risk, proxied by Directors' and Officers' liability insurance premiums, increases.
} 
further supports this theory. For instance, Naughton et al. [2019] study the effect of the US Supreme Court's Morrison ruling, which reduces shareholder litigation for foreign cross-listed firms under Rule 10b-5 of the Exchange Act, and find a reduction in voluntary disclosure in the post-Morrison period. Houston et al. [2019] examine various legal changes and conclude that litigation risk increases the frequency of managers' voluntary disclosures, particularly to preempt bad earnings news. Finally, Huang et al. [2019] use variation in federal judge ideology to proxy for expected litigation risk and find evidence consistent with the idea that firms increase bad news pre-disclosures to avoid earnings disappointments. ${ }^{6}$

At the same time, prior research also finds that managers carefully decide whether to disclose additional information for which they can be held accountable and choose to reduce voluntary disclosure to limit public scrutiny (Graham et al. [2005]). Johnson et al. [2001] examine the impact of the Private Securities Litigation Reform Act of 1995 on firms' voluntary disclosure choices and find an increase in earnings warnings in the short term before earnings announcements. Because the regulation reduced shareholder litigation risk by limiting the incidence of lawsuits based on unsubstantiated claims, this suggests that the threat of litigation decreases firms' bad news pre-disclosures. Also, Rogers and Van Buskirk [2009] explore a sample of sued firms and find that these firms reduce the provision of disclosures in the post-litigation period. ${ }^{7}$

While prior research primarily explores managers' response to shareholder litigation risk with public voluntary disclosure, an alternative strategy is to leak news privately through market participants such as analysts (e.g., Ajinkya and Gift [1984]; King et al. [1990]). In this regard, Matsumoto [2002] studies firms' incentives to adjust analysts' expectations when

\footnotetext{
${ }^{6}$ Bourveau et al. [2018] find that the implementation of universal demand laws, which reduced litigation risk, increases firms' voluntary disclosure. Huang et al. [2020] note that the seemingly contradictory evidence is due to the study's focus on long-term (instead of short-term) management forecasts. This highlights the importance to account for managers' differential incentives for voluntary disclosure in the short versus long term (e.g., Skinner [1994]; Healy and Palepu [2001]).

${ }^{7}$ The mixed evidence can be attributed to the endogenous relation between litigation risk and voluntary disclosure that arises due to measurement error in the litigation risk proxy (e.g., Kasznik and Lev [1995]; Field et al. [2005]; Huang et al. [2020]), time trends in class actions across industries (see Aganin [2021]), and reverse causality concerns. E.g., litigation risk can affect corporate policies such as financial disclosures (La Porta et al. [2006]) and voluntary disclosures can affect litigation costs (Francis et al. [1994]).
} 
shareholder litigation risk increases. Contrary to expectations, she does not find consistent evidence of a link between litigation risk and firms' use of expectations management to lower analysts' forecasts. Moreover, a recent study by Billings et al. [2021] examines firms' voluntary disclosure following litigation. They find that the frequency and probability of positive earnings surprises increase in the post-litigation period and conclude that managers' increased provision of public information helps firms to lower analysts' expectations. Again, this view does not consider the possibility that managers can choose private communication with analysts to influence market expectations.

\subsection{Private communication and the risk of regulatory enforcement actions}

In 2000, the SEC adopted Reg FD to limit public firms' selective disclosure of material information. Prior research indicates that Reg FD reduced private information flows to analysts (e.g., Gintschel and Markov [2004]; Francis et al. [2006]; Koch et al. [2012]). At the same time, the ruling has caused confusion about what material and private information means, leading to disagreeing views over the right interpretation of the ruling among both regulators and firms (Soltes [2018]). While SEC commissioners disagreed about the regulation and appropriate enforcement actions (Jordan [2004]), commentators raised concerns that analysts can still collect non-material information and build a material mosaic because managers can emphasize and refer back to issued statements (Unger [2001]). ${ }^{8}$

Prior research on firms' private communication with selected groups finds that the initial success of Reg FD did not last long, indicating that private communication is still widespread (e.g., Solomon and Soltes [2015]; Bushee et al. [2017, 2018]; Allee et al. [2020]; Johnson et al. [2020]; Campbell et al. [2021]). For instance, Green et al. [2014] document that investment conferences hosted by brokerages enable the host analysts to gather private information, and that host analysts' earnings forecasts are more timely and accurate following the conferences.

\footnotetext{
${ }^{8}$ According to the SEC, "an issuer is not prohibited from disclosing a non-material piece of information to an analyst, even if, ... that piece helps the analyst complete a "mosaic" of information that ... is material", and also arguing that "an issuer cannot render material information immaterial simply by breaking it into ostensibly non-material pieces" (SEC [2000]; Posner [2019]).
} 
Soltes [2014] examines proprietary records of a large-cap publicly traded firm and finds that the vast majority of private meetings occur over the phone (85\%). While analysts and managers do not meet during the two-week blackout period before earnings releases, a significant proportion of meetings occurs within 72 hours after public announcements. Survey and interview analyses conducted by Brown et al. [2015] further confirm the importance of manager-analyst private meetings after Reg FD, indicating that analysts favor phone calls with managers and rely on private communication to update their earnings forecasts.

Reg FD's limited effect can in part be attributed to irregular and weak enforcement actions by the SEC, a lack of clarity, and the difficulty in proving that firms have disclosed material and private information to favored groups (e.g., Solomon [2005]; Bengtzen [2017]; Soltes [2018]; Allee et al. [2020]). Since the enactment of Reg FD in 2000, the SEC has taken actions in only 18 cases, of which most were settled with no or low penalties (see Appendix B). In the last decade, the Netflix, Inc. case related to the disclosure of private information on social media sites received significant attention and led to new guidance from the SEC (SEC [2013]). In 2018, when Tesla, Inc.'s CEO Elon Musk posted misleading information on Twitter, the SEC imposed the largest Reg FD-fine ever on both the firm and Musk.

Yet, confusion about the appropriate disclosure of information to analysts remains (Soltes [2018]). When the SEC took the Siebel Systems case to court in 2005, the case was dismissed by a federal judge because it could not be proven that the firm's private statements to selected analysts and investors were material. This event marked a milestone in firms' perception about Reg FD liability concerns (Allee et al. [2020]) and signaled to managers that they are unlikely to be held liable when providing information selectively (e.g., Solomon [2005]; Fisch [2013]; Allee et al. [2020]). Ever since, the SEC has investigated or imposed penalties in only six other cases that involved private communication of firms with analysts (see Appendix B). This suggests that firms' private disclosure of information through analysts is a viable alternative channel to leak information to market participants. 


\subsection{Research question and hypothesis}

The extant disclosure literature is largely based on the premise that firms can choose to withhold private information or use public voluntary disclosure to reveal this information (see e.g., Beyer et al. [2010b]). However, managers can also use private disclosure of information, such as through analysts, to indirectly adjust market expectations (e.g., Ajinkya and Gift [1984]; King et al. [1990]). Given the prevalence of manager-analyst private communication post-Reg FD (e.g., Soltes [2014]) and the fact that the market incorporates analysts' forecast revisions into stock prices (e.g., Gleason and Lee [2003]), private communication with analysts can be an effective strategy to influence market expectations. In this paper, I examine whether expected shareholder litigation risk increases firms' propensity to disclose private earnings warnings to analysts. Although private communication is not bound to bad news, in this setting, managers have incentives to pre-disclose bad news in the face of shareholder litigation risk (e.g., Healy and Palepu [2001]).

In fact, firms are frequently the target of securities class action lawsuits based on shareholders' claims that firms have violated the securities law. ${ }^{9}$ Plaintiff lawyers routinely argue that firms have provided misleading statements or omitted material pieces of information in their disclosures (e.g., Billings et al. [2021]) even when there is no legal merit (e.g., Bebchuk [1988]; Johnson et al. [2007]). Because these lawsuits are typically triggered by unexpected stock price drops (e.g., Langevoort [2009]; Levine [2014]), firms have incentives to disclose bad news in a timely fashion to reduce the threat of shareholder litigation and reputation damages (e.g, Skinner [1994]; Kasznik and Lev [1995]). Despite public voluntary disclosure, firms' private disclosure of earnings warnings through analysts can be a viable alternative channel to reduce the impact of bad news shocks around public information events.

I argue that private communication can be an important disclosure channel because market frictions can prevent firms from engaging in public voluntary disclosure. For instance, shareholder litigation risk can reduce managers' incentives to disclose publicly (e.g., John-

\footnotetext{
${ }^{9}$ In 2020 alone, a total of 334 class action lawsuits were filed in state and federal courts (Aganin [2021]).
} 
son et al. [2001]; Rogers et al. [2011]). Therefore, firms carefully decide whether to disclose additional information for which they can be held accountable (e.g., Graham et al. [2005]; Rogers and Van Buskirk [2009]). When market uncertainty increases, firms may also avoid public guidance because uncertainty may require firms to frequently revise their forecasts when these are no longer appropriate (Chen et al. [2011]). ${ }^{10}$ Finally, when firms hold proprietary information, they have incentives to leak this privately to analysts rather than publicly, because analysts can combine this information in a summary statistic (King et al. [1990]).

Given that bad news shocks can trigger shareholder legal actions against the firm (e.g., Graham et al. [2005]) and manager-analyst private communication is widespread post-Reg FD (e.g., Soltes [2014]), I argue that firms have incentives to provide private earnings warnings when they perceive an increased threat of shareholder litigation. I predict that managers' propensity to disclose earnings warnings privately increases when expected shareholder litigation risk increases, and state the hypothesis in alternative form:

H: Managers' propensity to provide short-term earnings warnings privately is higher when the risk of shareholder litigation is higher.

Ex-ante, it is unclear whether managers use private communication with analysts to leak relevant information to the market. Reg FD still prohibits the communication of new material information to third parties. Therefore, managers are expected to weigh off the costs and benefits associated with each disclosure choice. When the costs to privately communicate outweigh the benefits, the firm may refrain from doing so. For instance, firms' requirement to promptly disclose $8-\mathrm{K}$ filings to release material information has led to a recent decline in voluntary public disclosure (Noh et al. [2019]), which can either mean that firms now choose private disclosure or that firms also refrain from leaking news privately. Billings et al. [2021] further find that firms' strategic provision of public information following shareholder litigation helps to reduce analysts' forecasts. Whether firms additionally choose private disclosure through analysts is therefore an empirical question.

\footnotetext{
${ }^{10}$ For instance, Apple Inc. did not guide 2020Q3 because the firm was uncertain about the extent of operational disruptions caused by the Covid-19 pandemic.
} 


\section{Measurement of key variables, research design, data, and sample}

\subsection{Measuring firms' private disclosure of earnings warnings}

When testing theories about managers' incentives for private communication, researchers face an econometric challenge since private communication is unobservable. Empiricists rely on indirect, observable proxies to infer private communication. For instance, in the expectations management literature, Matsumoto [2002] and Johnson et al. [2020] employ observable firm characteristics to measure firms' incentives to lower analysts' expectations, and Richardson et al. [2004] and Ke and Yu [2006] use analysts' forecast walk-down to proxy for managers' incentives to guide expectations. In the private communication literature, researchers use confidential data (Soltes [2014]; Solomon and Soltes [2015]), interview and survey analysis (Brown et al. [2015]), and innovative research designs, e.g., corporate jet patterns (Bushee et al. [2018]), to explore investors' and analysts' preferred access to private meetings with managers.

To identify private communication, I propose a novel measure motivated by the observation that analysts' and "other" forecasters' earnings forecast revisions diverge around quarterly earnings releases (Schafhäutle and Veenman [2021]). While analysts systematically lower their short-term earnings forecasts during the days of firms' earnings announcements, other forecasters do not revise estimates as strongly downwards. I exploit this difference to capture the likelihood that managers provide private earnings warnings to analysts.

Figure 1 illustrates the setting's timeline corresponding to the calculation of key variables. At quarter $q-1$ earnings releases, analysts update earnings forecasts for quarter $q$ using public and private information. At the same time, a group of benchmark forecasters revises quarter $q$ forecasts using public information only. To capture the likelihood that analysts' forecast revisions are due to firms' private information, I examine differences between analysts' and benchmark forecasters' forecast revisions around quarter $q-1$ earnings releases. Individual analyst and mean benchmark forecasters' revisions are calculated as the difference between $t+10$ and $t-1$ earnings forecasts, where $t$ is the day of the quarter $q-1$ earnings release. The 
choice of this measurement window is motivated by Soltes [2014], who finds that manageranalyst private meetings cluster just after public announcements.

By using benchmark forecasters as a control group, I can control for analysts' earnings forecast revisions following public news and estimate the likelihood that analysts' incremental revisions is due to managers' private disclosure of information:

$$
\text { Private_Revision }_{j i q}=\Delta F_{j i q}^{\text {Analyst }}-\Delta F_{i q}^{\text {Control }},
$$

where superscripts Analyst and Control refer to analysts and the control group of benchmark forecasters, respectively. The subscripts $j, i$, and $q$ refer to analyst, firm, and year-quarter, respectively. Private_Revision helps to flag analysts who are likely to receive private information around earnings releases. $\Delta F$ is an analyst's (the control group's mean) earnings forecast revision. I assume that a negative (positive) value of Private_Revision indicates that analysts anticipate worse (better) performance than the control group, because managers emphasize bad (good) news in private meetings with analysts.

There are two concerns with this measure. First, it is difficult to argue that the variable captures the extent of analysts' forecast revisions solely due to firms' private communication. ${ }^{11}$ Second, I have no priors on the effect of litigation risk on the extent of private information leakages. Since I am interested in managers' private communication strategy, I rely on a measure capturing the probability that managers disclose bad news to analysts:

$$
\text { Private_Warn }_{j i t}= \begin{cases}1, & \text { if } \Delta F_{j i t}^{\text {Analyst }}<\Delta F_{i t}^{\text {Control }} \\ 0, & \text { otherwise }\end{cases}
$$

where Private_Warn jit $_{\text {is }}$ an indicator variable that is equal to 1 when analysts' forecast revisions are strictly smaller than those of the control group, and 0 otherwise. Using this indicator variable, I can construct a firm-level measure of firms' propensity to leak bad news

\footnotetext{
${ }^{11}$ I acknowledge concerns that my key variables might capture analysts' incentives to bias earnings forecasts (e.g., analysts cater to the needs of large investors who prefer slightly pessimistic forecasts (Brown et al. [2015])) and to selectively update earnings forecasts when new information becomes available (e.g., analysts are more likely to incorporate bad news than good news (Berger et al. [2019])). In Section 4.2, I present validation tests of my private communication measure.
} 
privately to analysts $\left(\right.$ Firm_Private_$_{-}$Warn $\left._{i q}\right)$, as the fraction of analysts $(N)$ following firm $i$ at quarter $q-1$ earnings releases who are likely to receive private earnings warnings:

$$
\text { Firm_Private_Warn }_{i q}=\frac{1}{N_{i q}} \sum_{j=1}^{N_{i q}} \text { Private_Warn }_{j i q}
$$

This measure rests on the assumption that I can set up a convincing control group of benchmark forecasters to control for analysts' forecast revisions following public news. To construct such a control group, I obtain data on contributors from Estimize, an online financial forecasting platform. ${ }^{12}$ The selection of benchmark forecasters on Estimize follows a rigorous sample selection procedure to satisfy the following two assumptions. First, benchmark forecasters are unlikely to meet privately with managers. Second, benchmark forecasters are neither employed by brokerage houses nor investment banks and thus are unlikely to have conflicts of interests to please managers.

Using Estimize data, I receive detailed insights into a diverse pool of forecasters. The granularity of this data set allows me to examine users' disclosed background characteristics as summarized in Appendix C. Based on Brown and Khavis [2018], who confirm the reliability of Estimize users' background profiles, I retain user observations identified as professional (buy-side and independent analysts) and non-professional (e.g., academics, students, and other working professionals) forecasters. I eliminate those identified as sell-side analysts. ${ }^{13} \mathrm{I}$ also drop anonymous user observations to reduce noise in the control group and the concern that their intentions to forecast are less credible (Dyer and Kim [2021]). Hence, the selected benchmark forecasters are unlikely to meet privately with managers.

Next, benchmark forecasters are unlikely to have incentives to please managers. While it is not intuitive that individuals share their private information freely on online platforms, prior research suggests that they do so to improve their reputation (Wasko and Faraj [2005]), career, and problem-solving skills (Lakhani et al. [2007]), and to be entertained (Brabham

\footnotetext{
${ }^{12}$ Further information on Estimize's institutional settings is provided by Jame et al. [2016].

${ }^{13}$ I retain forecasts submitted by buy-side analysts because prior research finds that they strongly rely on quantitative and less on private information compared to sell-side analysts (Brown et al. [2015]).
} 
[2008]). In the online forecasting context, Crawford et al. [2018] find that buy-side analysts disclose their private information on SumZero to advance their career, improve their reputation with investing clients, and ensure that market prices reflect fundamental values. On Estimize, users' incentives include learning, reputation building, and the contribution to an unbiased set of market expectations. The participation and content are free. The platform promotes users for accuracy and also protects data quality by reviewing and verifying users' submitted forecasts. Overall, the set up of Estimize's online environment suggests that users are incentivized to share high-quality information (Chang and Chuang [2011]). ${ }^{14}$

Recent studies confirm the usefulness of online financial forecasting to the capital market. For instance, Jame et al. [2016] find that crowdsourced estimates convey unique information to the market because these forecasts are less biased and contain more recent information than those of analysts. Importantly, the value of online financial forecasting increases with the diversity of users (Adebambo et al. [2017]). Campbell et al. [2019] support this notion and find that non-professional research reports written on SeekingAlpha, a social media platform for investment research, provide unique value to investors.

\subsection{Measuring expected shareholder litigation risk}

I measure variation in ex-ante shareholder litigation risk using data on judge ideology from Huang et al. [2019]. Drawing from the political science literature and exploiting variation in judges' appointment by Democrats versus Republicans, Huang et al. [2019] measure judge ideology by the extent to which judges take a liberal versus conservative standpoint. Because federal judges are appointed by the president of the United States and presidents tend to choose judges with a similar political orientation, judges appointed by Democrats versus Republicans can be classified on a liberal (pro-shareholder) versus conservative (pro-firm) dimension (e.g., Baum [1992]; Grofman and Brazill [2002]; Epstein et al. [2007]). ${ }^{15}$

\footnotetext{
${ }^{14}$ See also Estimize.com and Gillam et al. [2017] for information about Estimize user incentives.

${ }^{15}$ In political science, researchers have introduced and measured judge ideology before Huang et al. [2019] (see e.g., Giles et al. [2001]; Epstein et al. [2007]; Boyd [2015]).
} 
The empirical strategy underlying the measure of litigation risk rests on the argument that judges use discretion in their decision-making. Prior research supports that case outcomes are influenced by judges' and justices' political orientations (e.g., Posner [2005]; Coffee [2015] and Epstein et al. [2012], respectively) and concludes that liberal judges impose a greater threat to firms' success in winning in court (e.g., Sullivan and Thompson [2004]; Ventoruzzo and Fedderke [2016]). Using federal judge ideology, Huang et al. [2019] measure firms' perceived litigation risk by estimating the probability that a panel of three randomly selected federal circuit court judges is dominated by liberal judges.

Huang et al. [2019] measure judge ideology on the federal circuit level as securities class action lawsuits are rarely if ever heard by the Supreme Court (Choi and Pritchard [2012]). ${ }^{16}$ Judges in circuit and district courts rule on most of these lawsuits. Because circuit judges can review and reverse decisions made by district judges and district judges care about their reputation and career, prior research finds that the ideology of circuit judges is strongly reflected in rulings by district judges (Choi et al. [2012]). Therefore, Huang et al. [2019] capture ex-ante litigation risk directly on the circuit level and indirectly on the district level where securities class action lawsuits are heard. Although it seems reasonable to assume that plaintiffs go to the court where they expect the most favorable outcomes, this is not common practice. The relevant circuit court is geographically bound to firms' headquarter. This suggests that firms can form expectations about the probability that a panel of three randomly selected judges in a circuit will decide in favor of shareholders. ${ }^{17}$

\subsection{Empirical strategy}

The linear equation below is used to estimate the relation between the threat of shareholder litigation and firms' propensity to disclose private earnings warnings:

$$
\text { Firm_Private_Warn }_{i q}=\beta_{1} \text { Litigation_Risk }_{i q}+\mathbf{X}_{i q} \delta+\alpha_{k}+\alpha_{q}+\varepsilon_{i q}
$$

\footnotetext{
${ }^{16}$ Only about $1-2 \%$ of cases appealing to the Supreme Court are heard. See uscourts.gov.

${ }^{17}$ See Huang et al. [2019] for a detailed summary of the theory and the development of the proxy.
} 
where subscripts $i$ and $q$ refer to firm and year-quarter, respectively. Firm_Private_Warn is the self-constructed proxy for firms' propensity to leak bad news to analysts. Litigation_Risk captures firms' expected shareholder litigation risk based on variation in federal judge ideology bound to firms' headquarter. $\mathbf{X}$ is a vector of observable control variables. $\alpha_{k}$ reflects circuit fixed effects to control for unobservable factors across circuits. ${ }^{18} \alpha_{q}$ is year-quarter fixed effects to control for macroeconomic trends, changes in the political landscape, and trends in class action lawsuit filings over time. I estimate equation (4) using OLS and cluster standard errors at the firm and year-quarter level. If firms' propensity to leak bad news privately to analysts increases when expected litigation risk increases, I expect $\beta_{1}>0$.

I include controls for firms' issuance of public guidance because firms can have different incentives to engage in public versus private communication (Versano and Trueman [2017]) and successfully guide analysts' expectations issuing public forecasts (Cotter et al. [2006]). I control for the level of the earnings surprise, whether a firm meets or misses earnings targets, and whether a firm reports a loss to account for analysts' and benchmark forecasters' reactions to public news and anticipated firm performance. Other control variables that are associated with Litigation_Risk include industry returns, market returns, state political leanings, and whether a firm operates in a high litigation risk industry (Huang et al. [2019]). Finally, I include variables linked to managers' strategic guidance behavior, i.e., firm size, market to book, sales growth, and analyst coverage (Johnson et al. [2020]), and the fraction of institutional investors, because analysts cater to the needs of large investors (e.g., Brown et al. [2015]; Johnson et al. [2020]). I present the variable definitions in Appendix A.

Three issues can arise when estimating equation (4). Underlying these concerns is the unobservability of both variables of interest. First, when Firm_Private_Warn is measured with error, this can yield inconsistent estimates when the measurement error is correlated with the independent variable. Using an instrumental variable to proxy for ex-ante litigation risk has the advantage that the variable is unaffected by managers' communication strate-

\footnotetext{
${ }^{18}$ Alternatively, I include firm fixed effects to control for constant unobservable firm characteristics.
} 
gies. The key identifying assumption is therefore that Litigation_Risk is plausibly exogenous. Second, any difference between the true threat of litigation and my proxy can induce measurement error in $\beta_{1}$. Third, to confidently interpret the estimated coefficient $\beta_{1}$, I rely on the assumption that Litigation_Risk is uncorrelated with the error term $\varepsilon$. However, $\mathbf{X}$ may omit an unobservable variable in the vector of controls that can be correlated with litigation risk and managers' communication strategies (see Roberts and Whited [2013]).

My empirical strategy addresses these concerns. I present a firm-specific, time-varying proxy for managers' propensity to disclose bad news privately and use Huang et al.'s [2019] plausibly exogenous proxy for ex-ante litigation risk. The definitions and measurements of both variables are described in Section 3.1 and 3.2, respectively. To increase confidence in my results, I include an extensive list of control variables associated with the independent and dependent variables and fixed effects structures. Yet, concerns may remain that my measure of Litigation_Risk is not as good as randomly assigned. While judges are randomly assigned to a case, judge ideology can capture location- and time-specific characteristics. I thus rely on Huang et al. [2019] who validate their proxy for ex-ante litigation risk. Given that litigation risk is a function of the likelihood that shareholders can take legal action against a firm and that a randomly selected panel of three judges decides in favor of shareholders, they find that judge ideology has a significant and economic impact on firms' likelihood to be sued and court case outcomes. ${ }^{19}$

\subsection{Data sources and sample construction}

I combine data from CRSP, Compustat, Estimize, I/B/E/S, Thomson Reuters 13f, and Huang et al. [2019] from calendar-quarters 2012Q1 to 2019Q2. ${ }^{20}$ My initial sample consists of US firms from CRSP-Compustat Merged, including firms with a primary listing

\footnotetext{
${ }^{19}$ Huang et al. [2019] present various validation tests. E.g., across firms, judge ideology plays a larger role when the fraction of institutional investors is higher. Over time, an increase in litigation risk predicts an increase in the frequency of lawsuit filings. Also, the market reacts negatively (positively) to the appointment of liberal (conservative) judges. Still, a concern remains that estimated ex-ante judge ideology is different from actual judge ideology and thus understates the true effect of litigation risk.

${ }^{20}$ Prior to 2012Q1, Estimize coverage is too limited for my study.
} 
on NYSE/AMEX/Nasdaq and firm-quarter observations with non-negative assets and nonmissing SIC, CIK, and reporting dates identifiers. I attach the sample of earnings forecast revisions from I/B/E/S unadjusted detail history and Estimize, after linking each Estimize firm to common firm identifiers, i.e., GVKEY, CUSIP, PERMNO, CIK, and I/B/E/S ticker.

I focus on quarter $q$ earnings forecasts that are revised around the days of quarter $q-1$ earnings releases. Section 3.1 and Appendix A describe the computation of the variables. Because the construction of forecast revisions depends on accurately identified earnings reporting dates on I/B/E/S and Estimize, I initially identify precise reporting dates. That is, I use the reporting date when all three and at least two of the following data sets agree on the date variable: CRSP-Compustat, Estimize, and I/B/E/S. For the ten firm-quarter observations for which the data sets record different reporting dates, I hand-collect the precise dates from firms' 8-K's.

I next attach data on control variables, firms' historical headquarter location, and Huang et al.'s [2019] proxy for litigation risk. Following Huang et al. [2019], judge ideology is measured at the circuit court level and captures the risk of securities class action lawsuits filed in firms' headquarter location. Unfortunately, Compustat backfills firms' historical headquarter addresses and provides only the current location, which can increase measurement error and severely bias results (Jennings et al. [2021]). I therefore use the recorded historical headquarter locations (HLOC) from CRSP-Compustat Merged. Finally, I attach hand-collected data on a state's political leaning (Blue_State), which captures the voting outcome of the presidential elections per state and over time. ${ }^{21}$

Panel A of Table 1 outlines the sample selection for sell-side analysts. Panel B of Table 1 presents the sample selection for the control group of benchmark forecasters. The selected control group consists of $10 \%$ buy-side analysts, $12 \%$ independent analysts, and $78 \%$ nonprofessional benchmark forecasters ( 5,157 benchmark forecasters). Within the group of buy-

\footnotetext{
${ }^{21}$ Control variables are measured at quarter $q-1$ fiscal-end. Earnings news control variables are attached to the days of quarter $q-1$ earnings announcements. Litigation risk is measured at the end of each month and attached one month before quarter $q-1$ earnings announcements.
} 
side analysts, hedge fund (197) and asset manager (169) are the most frequently identified professions. Within the group of non-professional benchmark forecasters, most users are employed in Information Technology (1,025), Software (340), IT Services (289), and Internet Software and Services (232) (untabulated).

Panel $\mathrm{C}$ of Table 1 summarizes the main sample selection. After eliminating observations missing data on relevant variables, I obtain a final sample of 12,618 firm-quarter observations, reflecting 1,640 unique firms from 2012Q1 until 2019Q2. In analyst-level tests, I require the availability of additional analyst-level control variables using the I/B/E/S recommendations Detail and Unadjusted Detail History files. For these tests, I obtain a final sample of 131,785 analyst-firm-quarter observations, including 3,173 unique analysts following 1,601 unique firms from 2012Q1 until 2019Q2.

\section{Results}

\subsection{Descriptive statistics}

Panel A of Table 2 presents the summary statistics for the firm-quarter sample. Around quarter $q-1$ earnings announcements, the control group's mean revision of quarter $q$ earnings forecasts is -0.49 cents $\left(\Delta F^{\text {Control }}\right)$, while analysts' mean revision of forecasts is -2.8 cents

$\left(\Delta F^{\text {Analyst }}\right)$ (unscaled). The negative sign suggests that analysts' forecasts are on average revised more downwards than upwards. To illustrate the differences in forecast revisions between analysts and benchmark forecasters, Figure 2 displays both groups' median earnings forecast revisions in event time. The graph illustrates that analysts strongly lower their forecasts (scaled by price) around event days 0 and 1 , which is when the firm reports quarterly earnings. In contrast, benchmark forecasters do not seem to lower their forecasts as strongly.

The descriptive statistics suggest that analysts decrease their earnings forecasts by an average of 2.35 cents more than the control group (Private_Revision). This variable helps to estimate the probability that analysts' incremental revisions are due to firms' private disclosure of earnings warnings given that only analysts have access to private meetings with 
managers (e.g., Soltes [2014]). As discussed, the variable Firm_Private_Warn estimates variation in managers' propensity to leak bad news privately to analysts. The distribution of this variable suggests that firms are more likely to engage in private communication with analysts to preempt bad news than good news. Figure 3 further presents the distribution of Firm_Private_Warn and illustrates that many firms cluster in the extremes. A value of 1 (0) suggests that all analysts following firm $i$ at quarter $q-1$ are likely to receive bad (good) news from managers.

Next, the mean of Litigation_Risk is $47 \%$. A value less than $50 \%$ indicates that a panel of three randomly selected circuit court judges is more likely to decide in favor of firms rather than shareholders. Generally, there is substantial variation in litigation risk across circuits, which stems from changes in federal circuit judges' composition. During my sample period, the 2nd and 9th Circuits are the most liberal and the 7th and 8th Circuits are the most conservative. For instance, in the 9th Circuit, the probability that a panel is dominated by liberal judges is $68 \%$, but in the 8 th Circuit, the probability is only $3 \%$. Litigation risk also varies over time. While the 1st Circuit becomes more liberal (15\% in 2012 to $42 \%$ in 2019), the 7 th Circuit becomes more conservative (16\% in 2012 to $3 \%$ in 2019) (untabulated). ${ }^{22}$ Figure 4 further presents the annual distribution of shareholder litigation risk based on judge ideology. In line with the presidential elections during my sample period, I find an increase in judge ideology from 2012 until 2017 and a decrease subsequently.

Regarding firm controls, I find that $26 \%$ of firm-quarters provide public guidance and $24 \%$ report a loss. The median firm-quarter earnings surprise is 3.22 cents per share. This corresponds to an average of $76 \%$ of firm-quarters that meet or beat quarterly earnings consensus forecasts. The sample statistics are skewed towards large (median $M V$ is 6 billion USD) and high growth firms (median $M B$ is 3.16). The mean (median) analyst coverage is 12 (11) and the mean (median) fraction of institutional investors is $54 \%$ (72\%). Because this sample requires the availability of Estimize benchmark forecasters who initiated coverage of

\footnotetext{
${ }^{22}$ Most sample firms are historically headquartered in the 2nd, 5th, and 9th Circuits.
} 
large firms in the initial years (Schafhäutle and Veenman [2021]), the sample firms are larger than those in related research (e.g., Green et al. [2014]).

Panel B of Table 2 presents the mean values of the variables split on low versus high litigation risk. ${ }^{23}$ First, I find a slightly higher mean value for Firm_Private_Warn in the high-litigation risk partition. This difference is significant at the $5 \%$ level and is consistent with my hypothesis that firms are more likely to leak bad news privately when expected shareholder litigation risk increases. Second, there are significant differences among the covariates. Firms in the high-litigation risk partition report more positive earnings surprises, more losses, and are larger than in the low-litigation risk partition. These insights suggest the need to control for observable firm characteristics in the empirical analyses.

Finally, Panel D of Table 2 illustrates the sample distribution across industries and associated mean values of Firm_Private_Warn. Most firms are identified in the (1) business equipment, (2) wholesale, retail, and some services, and (3) other industries. Firms' propensity to leak bad news to analysts is highest in the consumer non-durables $(63.95 \%)$, followed by chemicals and allied products $(55.66 \%)$ and consumer durables $(55.23 \%)$. In contrast, firms' propensity to leak bad news is low in regulated industries, such as utilities (39.22\%) and oil, gas, and extraction (42.95\%).

\subsection{Validation tests}

\subsubsection{Do analysts with preferred access to managers receive private earnings warnings?}

In this section, I validate Private_Warn as a proxy for the probability that managers leak bad news privately, which underlies the main variable (i.e., Firm_Private_Warn). As prior research suggests, private access to managers varies predictably across analysts. Analysts who issue positive stock recommendations are more likely to receive inside information than those who issue negative stock recommendations (e.g., Chen and Matsumoto [2006]; Mayew

\footnotetext{
${ }^{23}$ I drop the variables underlying the main private communication proxy, as these are not used to test the hypothesis. I also drop Market_Ret since this variable is estimated for the entire pool of firms in a given firm-quarter.
} 
[2008]). If Private_Warn captures variation in the probability that managers leak bad news to analysts, I expect that analysts who hold a favorable (unfavorable) view of the firm are more (less) likely to receive such information.

To test this hypothesis, I estimate the equation below using a linear probability model:

$$
\begin{aligned}
\text { Private_Warn }_{j i q} & =\beta_{1} \text { Strong_Buy }_{j i q}+\beta_{2} \text { Buy } y_{j i q}+\beta_{3} \text { Sell }_{j i q} \\
& +\beta_{4} \text { Strong_Sell } \\
j i q & +\mathbf{X}_{j i q} \delta+\alpha_{i q}+\varepsilon_{j i q}
\end{aligned}
$$

where $j, i$, and $q$ refer to analyst, firm, and year-quarter, respectively. Strong_Buy, Buy, Sell, and Strong_Sell are indicator variables that refer to an analyst's final outstanding stock recommendation and proxy for analysts' preferred access to managers. $\alpha_{i q}$ is firmyear-quarter fixed effects and controls for constant unobservable factors across firm-yearquarter observations. Using this design, I can exploit within firm-year-quarter variation across analysts' characteristics to explain the probability that analysts receive private earnings warnings. $\mathbf{X}$ is a vector of control variables that help to rule out that alternative analysts' attributes, e.g., incentives to bias, determine Private_Warn. Standard errors are clustered at the analyst and year-quarter levels. I expect that $\beta_{1}>0$ and $\beta_{2}>0$ and that $\beta_{3}<0$ and $\beta_{4}<0$.

I control for analysts' forecast accuracy, general and firm experience, and brokerage size, which reflects analysts' level of resource availability (e.g., Clement [1999]). Because forecast accuracy can also proxy for private access to managers (e.g., Chen and Jiang [2006]; Ke and $\mathrm{Yu}[2006]$ ), analysts who issue more accurate forecasts may receive private information. I further control for brokerage house reputation (e.g., Hong and Kubik [2003]; Hilary and Hsu [2013]) and analysts' busyness based on the number of firms in their portfolio (e.g., Clement [1999]). The former recognizes that there is variation in analysts' credibility to move stock prices, but also potentially lowball estimates. The latter captures analysts' reliance on private information from managers when they are busy.

Panel C of Table 2 presents summary statistics on analyst-level variables. In line with prior research (e.g., Mayew [2008]), most analysts hold favorable views of firms (mean 
Strong_Buy is $20 \%$ and mean Buy is 34\%) and only $1 \%$ and $5 \%$ percent of analysts have an outstanding Sell and Strong_Sell stock recommendation, respectively. ${ }^{24}$ The mean brokerage house has 101 analysts employed in a given year. Analysts have between 0 and 24.5 years of firm experience and between 0.3 and 33 years of general experience. The average analyst covers 14 firms, but there is substantial variation across analysts' busyness covering between 1 and 37 firms. Finally, 33\% of analysts are employed at a prestigious brokerage house, including Deutsche Bank, Goldman Sachs, JPMorgan Chase \& Co., Merrill, and Morgan Stanley. ${ }^{25}$

The first column in Table 3 presents results from estimating equation (5). ${ }^{26}$ To facilitate interpretation of the independent variables and to control for the skewness in their distributions, all continuous variables are sorted into quarterly decile ranks (Bernard and Thomas [1990]) and subsequently transformed to a [-0.5; 0.5] scale (Mashruwala et al. [2006]). Consistent with the validation of my measure, I find that the probability of receiving bad news privately from managers is positively associated with the favorability of analysts' outstanding stock recommendations. Relative to neutral recommendations, Strong_Buy and Buy recommendations increase the probability that analysts receive private earnings warnings from managers by 3.4 and 2.6 percentage points, respectively.

The negative coefficient on Accuracy suggests that less accurate analysts are substantially less likely to receive private earnings warnings. ${ }^{27}$ Because accuracy also proxies for analysts' access to private information (e.g., Chen and Jiang [2006]), this result suggests that more accurate analysts are more likely to receive managers' private signals. The coefficient on Brokerage_Size is positive and significant, suggesting that analysts who work for larger rather than smaller brokerage houses are 3.4 percentage points more likely to receive bad news. Brokerage size captures not only analysts' resource availability but also their reputation.

\footnotetext{
${ }^{24}$ I exclude neutral stock opinions from my summary table.

${ }^{25}$ Brokerage names are hand-collected based on the masked ESTIMID and in combination with analysts' names provided by IBES recommendations detail.

${ }^{26}$ Estimated coefficients are presented including singleton observations. Statistical significance levels and estimated coefficients are only marginally affected when singleton observations are excluded.

${ }^{27}$ The variable is constructed as such that larger values indicate a higher degree of inaccuracy.
} 
Therefore, managers might provide preferred access to analysts associated with prestigious brokerages. Other analyst experience controls are not significantly related to the probability that analyst receive bad news privately from managers. Consistent with the idea that busy analysts rely on managers' private information, I find that the busiest analysts compared to the least busy are 3.1 percentage points more likely to rely on managers' private earnings warnings. Finally, Reputation does not incrementally explain Private_Warn, after controlling for other variables. ${ }^{28}$

In the second column, I use an alternative specification to test whether my results are sensitive to the empirical design choice and include firm controls. I include earnings news control variables to hold analysts' reactions to quarterly earnings news constant. I control for the fraction of institutional investors because analysts care about their credibility with investing clients (Brown et al. [2015]), and also, the number of analysts covering a firm because managers could be time-constraint to speak privately to all analysts. I also include firm and year-quarter fixed effects to control for time-invariant unobserved firm factors and unobserved time trends, respectively. Because analysts' stock recommendations are usually sticky over time, I do not include analyst fixed effects to reduce concerns of limited variation within the explanatory variables of interest (deHaan [2021]). ${ }^{29}$

Estimated coefficients and levels of statistical significance are similar to those in column one. Only Accuracy is not related to Private_Warn when additional controls are included. Three results stand out. Because analysts quickly revise their forecasts following firms' public voluntary earnings guidance (Cotter et al. [2006]), the insignificant relation between Public_Guidance and Private_Warn increases confidence that my proxy captures firms' private disclosure of information which can be an important alternative channel through which managers can leak earnings warnings indirectly to the market. ${ }^{30}$ Also, managers' provision

\footnotetext{
${ }^{28}$ Because analysts from prestigious brokerages have a greater influence on stock prices than less prestigious analysts (Stickel [1992]; Gleason and Lee [2003]), another effective strategy is to leak bad news to high reputation analysts (e.g., Mayew [2008]). In untabulated tests, I find no evidence for this alternative strategy.

${ }^{29}$ Significance levels and estimated signs on the coefficients in Table 3 are unaffected by alternative fixed effects structures, i.e. firm, year-quarter, and analyst fixed effects or analyst-firm fixed effects.

${ }^{30}$ The insignificant association is unsurprising given the empirical strategy to estimate private communi-
} 
of private earnings warnings is not determined by the number of analysts covering a firm, but an increase in the fraction of institutional investors is marginally significantly associated with Private_Warn. ${ }^{31}$

Finally, I repeat the analysis and exchange Private_Warn with a variable that measures the probability that analysts with favored access to managers receive either good or bad news. The results confirm my expectation that only analysts with favorable stock recommendations receive managers' private information, while unfavorable recommendations are not significantly related to the provision of managers' private signals (untabulated).

\subsubsection{The predictive ability of managers' propensity to leak bad news privately}

The results suggest that managers provide private earnings warnings to analysts with whom they are more likely to communicate. A potential alternative explanation, however, is that analysts who issue favorable stock recommendations please managers with pessimistic earnings forecasts, which helps the firm to meet the consensus forecast (e.g., Richardson et al. [2004]; Ke and Yu [2006]). To rule out this possibility, I present a second validation test. I argue that if my measure indeed captures firms' propensity to disclose bad news privately to analysts, it should be associated with future adverse news. Alternatively, if my measure simply picks up variation in analysts' strategies to pessimistically bias earnings forecasts, it should be positively related to firms' probability to meet the consensus forecasts.

Empirically, I construct an indicator variable equal to 1 when a firm reports negative earnings at the quarter $q$ earnings release (Future_Loss), and 0 otherwise. I also construct an indicator variable equal to 1 when a firm misses quarter $q$ earnings expectations (Future_Miss), and 0 otherwise. Additionally, I estimate future bad news as a continuous variable and account for earnings decreases because firms can report losses (miss expectations) already in the previous quarter. I include common firm controls associated with firms' probability to

cation and the assumption that I can control for analysts' reaction to public news using a control group.

${ }^{31}$ Estimating equation (5) using a logit model and employing Mayew's [2008] methodology to use peer group adjusted measures (analyst $j$ relative to other analysts following firm $i$ at quarter $q-1$ ), I confirm signs and statistical significance levels of estimates using OLS. 
report bad news as well as private communication, and also include year-quarter fixed effects. In an alternative specification, I add firm fixed effects. All continuous variables are sorted into quarterly decile ranks and subsequently transformed to a $[-0.5 ; 0.5]$ scale to control for skewness in the variables' distributions and facilitate the interpretation of the results.

Table 4 presents the results using a linear probability model and OLS to estimate the relation between firms' propensity to provide private earnings warnings and future bad news. The results consistently suggest that Firm_Private_Warn is positively associated with future bad news. That is, the reporting of quarterly losses and earnings decreases, as well as missing consensus expectations, are more likely for firms leaking bad news privately. For instance, I find that a one unit increase in my measure is associated with a 5.4 (2.8) percentage point increase in firms' probability to report negative news (miss analysts' consensus forecasts) in the next quarter. The results remain largely the same when I include firm fixed effects. Combined, the results increase confidence that my measure of managers' propensity to disclose private earnings warnings captures firms' private information flows instead of analysts' incentives to play the earnings game.

\subsection{Expected litigation risk and managers' propensity to leak bad news privately}

Table 5 presents the main results on the relation between expected litigation risk and managers' propensity to leak bad news privately. My hypothesis predicts that this relation is positive and significant. In the first column, I examine variation across firms but within a federal circuit while simultaneously controlling for unobserved time trends. In the second column, I exchange circuit fixed effects with firm fixed effects and also omit Litigation_Industry because it is collinear with firm fixed effects. All continuous variables are sorted into quarterly decile ranks and subsequently transformed to a $[-0.5 ; 0.5]$ scale to control for skewness in the variables' distributions and facilitate the interpretation of the results.

I find a significant positive relation between ex-ante litigation risk and managers' propen-

sity to communicate with analysts about bad news and hence can accept my hypothesis that 
managers are more likely to leak bad news privately when expected shareholder litigation risk increases. Exploiting variation across firms located in the same circuit in the first column, I find that the coefficient equals 0.179 , which implies a 4.1 percentage point increase in firms' propensity to provide private earnings warnings to analysts. ${ }^{32}$ The effect of litigation risk on private communication is larger within firms, as presented in the second column. The coefficient is 0.299 , which implies a 6.8 percentage point increase in firms' strategies to use private disclosure of earnings warnings to lower analysts' forecasts. ${ }^{33}$

Importantly, I find the result is found after controlling for firms' public voluntary disclosure of information. I also find that firms are less likely to leak bad news to analysts when they report positive earnings surprises and meet the consensus forecast. Across firms located in the same circuit, I find that control variables that are associated with managers' incentives to guide expectations are largely unrelated to managers' propensity to leak bad news privately. The coefficients on firm size and growth are not significant and the coefficient on sales growth is marginally significant but negative. These results further strengthen the idea that I can capture firms' private disclosure of earnings warnings and not incentives to guide expectations. I conclude that although firms can bundle positive and negative news (Bliss et al. [2018]), issue public earnings warnings (e.g., Skinner [1994]), and release 8-K filings (Noh et al. [2019]) to reduce shareholder litigation risk, managers can additionally engage in private communication to leak bad news through analysts to the market.

\subsection{Cross-sectional results}

Next, I exploit cross-sectional variation in the relation between firms' expected shareholder litigation risk and the propensity to provide private earnings warnings to analysts. Following prior research (e.g., Francis et al. [1994]; Correia and Klausner [2012]; Huang et al. [2019]; LaCroix [2020]), I expect that larger firms are more frequently the target of securities

\footnotetext{
${ }^{32}$ The standardized coefficient on Litigation_Risk is $0.179 \times \frac{0.2269}{0.3222}=0.1261$. Hence, an increase in ex-ante litigation risk by one standard deviation increases managers' propensity to leak bad news by $0.1261 \times 0.3222$.

${ }^{33}$ The results remain unchanged when I cluster standard errors at the state level following Huang et al. [2019].
} 
class action lawsuits because plaintiffs' expected payoffs increase in firm size. I therefore predict that larger firms have stronger incentives to leak bad news when the risk of shareholder litigation increases. This argument relates to Billings et al. [2021], who conclude that high visibility firms are more concerned about the costs associated with shareholder litigation and have stronger incentives to disclose bad news in a timely manner.

I estimate equation (4) by partitioning the sample in small versus large firms based on the median value of firms' market capitalization. The results are reported in Table 6. For presentation purposes, I do not report the control variables. I find that the previous results are concentrated among large firms. Across firms located in the same circuit, the coefficient on Litigation_Risk is higher for large firms than small firms and statistically significant at the $1 \%$ level only for large firms (see first and second columns). The difference in coefficients is statistically significant at the $5 \%$ level. Within firms, the effect is also concentrated among large firms, but the difference in coefficient estimates is not significant (see third and fourth columns). Taken together, the results confirm that the effect of shareholder litigation risk on managers' private communication strategy is concentrated in large firms.

\section{Discussion and conclusion}

Firms' private communication with analysts can be one potential disclosure channel used by managers to indirectly influence market expectations. While some prior studies have explored firms' use of private communication with selected market participants and frequently assume that firms provide information advantages to selected large investors and analysts, firms' use of private communication as an alternative voluntary disclosure channel remains relatively unexplored. In this paper, I provide a new perspective on firms' decision to voluntarily disclose by focusing on firms' use of private disclosure through analysts. Using shareholder litigation risk as one key motive for managers to disclose voluntarily (e.g., Skin-

ner [1994]), I examine whether managers disclose private earnings warnings when expected shareholder litigation risk increases. 
This paper estimates variation in managers' propensity to provide private earnings warnings using the difference between analysts' and a group of benchmark forecasters' revisions of short-term earnings forecasts around earnings announcements. Based on the argument that analysts and benchmark forecasters view and react to public news but only analysts have access to private meetings with managers, I approximate managers' propensity to leak bad news privately. Moreover, exploiting plausibly exogenous variation in ex-ante shareholder litigation risk based on judge ideology (Huang et al. [2019]), I find that firms' propensity to provide private earnings warnings increases when the threat of shareholder litigation increases. I finally document that this effect is concentrated among large firms that are more likely the target of shareholder legal actions.

My study contributes to the literatures on firms' disclosure choices in response to shareholder litigation risk and firms' private communication with analysts. Primarily, I focus on the idea that managers choose private communication as an alternative private voluntary disclosure channel to public voluntary disclosure. This paper does not argue that managers communicate material private information to lower expected litigation risk, nor does it make claims about the benefits of private versus public information disclosure. Given that Reg FD does not prohibit all private communication, I solely document the importance of managers' decision to privately disclose in a context where managers have incentives to leak bad news quickly. By demonstrating that managers' propensity to leak bad news privately increases when expected shareholder litigation risk increases, I conclude that managers react to the legal system and use private communication with analysts as an alternative disclosure channel to lower market expectations. I also conclude that, in such context, private communication could be beneficial to the market, as analysts can better anticipate firms' future performance and managers can reduce the risk of securities class action lawsuits, which can be costly to shareholders. 


\section{References}

Abarbanell, J. S. (1991). Do analysts' earnings forecasts incorporate information in prior stock price changes? Journal of Accounting and Economics, 14(2):147-165.

Adebambo, B., Bliss, B. A., and Kumar, A. (2017). Geography, Diversity, and Accuracy of Crowdsourced Earnings Forecasts. Available at SSRN: https://ssrn.com/abstract=2579402.

Aganin, A. (2021). Securities Class Action Filings - 2020 Year in Review. Technical report, Cornerstone Research, Inc.

Ajinkya, B. B. and Gift, M. J. (1984). Corporate Managers' Earnings Forecasts and Symmetrical Adjustments of Market Expectations. Journal of Accounting Research, 22(2):425.

Allee, K. D., Bushee, B. J., Kleppe, T. J., and Pierce, A. T. (2020). Did the Siebel Systems Case Limit the SEC's Ability to Enforce Regulation Fair Disclosure? Available at SSRN: https://ssrn.com/abstract $=3440155$.

Baum, L. (1992). Membership change and collective voting change in the United States Supreme Court. Journal of Politics, 54:3-24.

Bebchuk, L. A. (1988). Suing solely to extract a settlement offer. Journal of Legal Studies, $17: 437-450$.

Bengtzen, M. (2017). Private Investor Meetings in Public Firms: The Case for Increasing Transparency. Fordham Journal of Corporate and Financial Law, 22:33-132.

Berger, P. G., Ham, C. G., and Kaplan, Z. R. (2019). Do Analysts Say Anything About Earnings Without Revising Their Earnings Forecasts? The Accounting Review, 94(2):2952.

Bernard, V. L. and Thomas, J. K. (1990). Evidence that stock prices do not fully reflect the implications of current earnings for future earnings. Journal of Accounting and Economics, 13(4):305-340.

Beyer, A., Cohen, D. A., Lys, T. Z., and Walther, B. R. (2010a). The financial reporting environment: Review of the recent literature. Journal of Accounting and Economics, 50(2-3):296-343.

Beyer, A., Cohen, D. A., Lys, T. Z., and Walther, B. R. (2010b). The financial reporting environment: Review of the recent literature. Journal of Accounting and Economics, 50(2-3):296-343.

Billings, M. B., Cedergren, M. C., and Dube, S. (2021). Does litigation change managers' beliefs about the value of voluntarily disclosing bad news? Review of Accounting Studies, Forthcoming.

Bliss, B. A., Partnoy, F., and Furchtgott, M. (2018). Information bundling and securities litigation. Journal of Accounting and Economics, 65:61-84. 
Bourveau, T., Lou, Y., and Wang, R. (2018). Shareholder Litigation and Corporate Disclosure: Evidence from Derivative Lawsuits. Journal of Accounting Research, 56(3):797-842.

Boyd, C. (2015). Federal District Court Judge Ideology Data. Available at: http://cLboyd.net/ideology.html.

Brabham, D. C. (2008). Moving the crowd at iStockphoto: The composition of the crowd and motivations for participation in a crowdsourcing application. First Monday, 13(6).

Brown, L. D., Call, A. C., Clement, M. B., and Sharp, N. Y. (2015). Inside the "Black Box" of Sell-Side Financial Analysts. Journal of Accounting Research, 53(1):1-47.

Brown, L. D. and Khavis, J. (2018). The Reliability of Crowdsourced Earnings Forecasts. Fox School of Business Research Paper, No. 18-001.

Bushee, B. J., Gerakos, J., and Lee, L. F. (2018). Corporate jets and private meetings with investors. Journal of Accounting and Economics, 65(2-3):358-379.

Bushee, B. J., Jung, M. J., and Miller, G. S. (2017). Do Investors Benefit from Selective Access to Management? Journal of Financial Reporting, 2:31-61.

Campbell, J. L., DeAngelis, M. D., and Moon, J. R. (2019). Skin in the game: personal stock holdings and investors' response to stock analysis on social media. Review of Accounting Studies, 24(3):731-779.

Campbell, J. L., Twedt, B. J., and Whipple, B. C. (2021). Trading Prior to the Disclosure of Material Information: Evidence from Regulation Fair Disclosure Form. Contemporary Accounting Research, 38(1):412-442.

Cao, Z. and Narayanamoorthy, G. S. (2011). The Effect of Litigation Risk on Management Earnings Forecasts*: Effect of Litigation Risk on Earnings Forecasts. Contemporary Accounting Research, 28(1):125-173.

Chang, H. H. and Chuang, S.-S. (2011). Social capital and individual motivations on knowledge sharing: Participant involvement as a moderator. Information and Management, 48(1):9-18.

Chen, Q. and Jiang, W. (2006). Analysts' Weighting of Private and Public Information. Review of Financial Studies, 19(1):319-355.

Chen, S., Matsumoto, D., and Rajgopal, S. (2011). Is silence golden? An empirical analysis of firms that stop giving quarterly earnings guidance. Journal of Accounting and Economics, 51(1-2):134-150.

Chen, S. and Matsumoto, D. A. (2006). Favorable versus Unfavorable Recommendations: The Impact on Analyst Access to Management-Provided Information. Journal of Accounting Research, 44(4):657-689. 
Choi, S., Gulati, M., and Posner, E. A. (2012). What Do Federal District Judges Want? An Analysis of Publications, Citations, and Reversals. Journal of Law, Economics $\&$ Organization, 28(3):518-549.

Choi, S. J. and Pritchard, A. C. (2012). The Supreme Court's Impact on Securities Class Actions: An Empirical Assessment of Tellabs. Journal of Law, Economics, EG Organization, 28(4):850-881.

Clement, M. B. (1999). Analyst forecast accuracy: Do ability, resources, and portfolio complexity matter? Journal of Accounting and Economics, 27(3):285-303.

Clement, M. B., Hales, J., and Xue, Y. (2011). Understanding analysts' use of stock returns and other analysts' revisions when forecasting earnings. Journal of Accounting and Economics, 51(3):279-299.

Coffee, J. C. (2015). Entrepreneurial litigation: Its Rise Fall and Future. Harvard University Press.

Correia, M. and Klausner, M. (2012). Are Securities Class Actions 'Supplemental' to SEC Enforcement? An Empirical Analysis. Stanford Law School Stanford, Calif Working Paper.

Cotter, J., Tuna, I., and Wysocki, P. D. (2006). Expectations Management and Beatable Targets: How Do Analysts React to Explicit Earnings Guidance? Contemporary Accounting Research, 23(3):593-628.

Crawford, S., Gray, W., Johnson, B. R., and Price, R. A. (2018). What Motivates Buy-Side Analysts to Share Recommendations Online? Management Science, 64(6):2574-2589.

deHaan, E. (2021). Using and Interpreting Fixed Effects Models. Available at SSRN: https://ssrn.com/abstract=36997rm.

Dyer, T. and Kim, E. (2021). Anonymous Equity Research. Journal of Accounting Research, Forthcoming.

Epstein, L., Landes, W. M., and Posner, R. A. (2012). How business fares in the supreme court. Minnesota Law Review, 97:1431.

Epstein, L., Martin, A. D., Segal, J. A., and Westerland, C. (2007). The Judicial Common Space. Journal of Law, Economics $\mathscr{G}$ Organization, 23(2):303-325.

Field, L., Lowry, M., and Shu, S. (2005). Does disclosure deter or trigger litigation? Journal of Accounting and Economics, 39(3):487-507.

Fisch, J. E. (2013). Regulation FD: An Alternative Approach to Addressing Information Asymmetry. Faculty Scholarship at Penn Law., 407.

Francis, J., Nanda, D., and Wang, X. (2006). Re-examining the effects of regulation fair disclosure using foreign listed firms to control for concurrent shocks. Journal of Accounting and Economics, 41(3):271-292. 
Francis, J., Philbrick, D., and Schipper, K. (1994). Shareholder Litigation and Corporate Disclosures. Journal of Accounting Research, 32(2):137-164.

Giles, M. W., Hettinger, V. A., and Peppers, T. (2001). Picking Federal Judges: A Note on Policy and Partisan Selection Agendas. Political Research Quaterly, 54(3):623-641.

Gillam, R. A., Samorajski, G. S., and Drogen, L. (2017). Improving Earnings Forecasts with Estimize Crowd Sourced Data. McKinley Management LLC, Available at https://www.mckinleycapital.com/improving-earnings-forecasts-with-estimizecrowd-sourced-data/.

Gintschel, A. and Markov, S. (2004). The effectiveness of Regulation FD. Journal of Accounting and Economics, 37(3):293-314.

Gleason, C. A. and Lee, C. M. C. (2003). Analyst Forecast Revisions and Market Price Discovery. The Accounting Review, 78(1):193-225.

Graham, J. R., Harvey, C. R., and Rajgopal, S. (2005). The economic implications of corporate financial reporting. Journal of Accounting and Economics, 40(1-3):3-73.

Green, T. C., Jame, R., Markov, S., and Subasi, M. (2014). Access to Management and the Informativeness of Analyst Research. Journal of Financial Economics, 114:239-255.

Grofman, B. and Brazill, T. J. (2002). Identifying the median justice on the Supreme Court through multidimensional scaling: Analysis of "natural courts" 1953-1991. Public Choice, 112:55-79.

Healy, P. M. and Palepu, K. G. (2001). Information asymmetry, corporate disclosure, and the capital markets: A review of the empirical disclosure literature. Journal of Accounting and Economics, 31:405-440.

Hilary, G. and Hsu, C. (2013). Analyst Forecast Consistency. The Journal of Finance, 68(1):271-297.

Hong, H. and Kubik, J. D. (2003). Analyzing the Analysts: Career Concerns and Biased Earnings Forecasts. The Journal of Finance, 58(1):313-351.

Houston, J. F., Lin, C., Liu, S., and Wei, L. (2019). Litigation Risk and Voluntary Disclosure: Evidence from Legal Changes. The Accounting Review, 94(5):247-272.

Huang, A., Hui, K. W., and Li, R. Z. (2019). Federal Judge Ideology: A New Measure of Ex Ante Litigation Risk. Journal of Accounting Research, 57(2):431-489.

Huang, Y., Li, N., Yu, Y., and Zhou, X. (2020). The Effect of Managerial Litigation Risk on Earnings Warnings: Evidence from a Natural Experiment. Journal of Accounting Research, 58(5):1161-1202.

Jame, R., Johnston, R., Markov, S., and Wolfe, M. C. (2016). The Value of Crowdsourced Earnings Forecasts. Journal of Accounting Research, 54(4):1077-1110. 
Jennings, J. N., Kim, J. M., Lee, J. A., and Taylor, D. J. (2021). Measurement Error and Bias in Causal Models in Accounting Research. Available at SSRN: https://ssrn.com/abstract=373119\%.

Johnson, M. F., Kasznik, R., and Nelson, K. K. (2001). The Impact of Securities Litigation Reform on the Disclosure of Forward-Looking Information By High Technology Firms. Journal of Accounting Research, 39(2):297-327.

Johnson, M. F., Nelson, K. K., and Pritchard, A. (2007). Do the merits matter more? The impact of the private securities litigation reform act. The Journal of Law, Economics, and Organization, 23(3):627-652.

Johnson, T. L., Kim, J., and So, E. (2020). Expectations Management and Stock Returns. The Review of Financial Studies, 33(10):4580-4626.

Jordan, J. (2004). Corporate Issuers Beware: Schering-Plough and Recent SEC Enforcement Actions Signal Vigorous Enforcement of Regulation FD. University of Miami Law Review, $58(3): 751$.

Kasznik, R. and Lev, B. (1995). To Warn or Not to Warn: Management Disclosures in the Face of an Earnings Surprise. The Accounting Review, 70(1):113-134.

Ke, B. and Yu, Y. (2006). The Effect of Issuing Biased Earnings Forecasts on Analysts' Access to Management and Survival. Journal of Accounting Research, 44(5):965-999.

King, R., Pownall, G., and Waymire, G. (1990). Expectations Adjustment Via Timely Management Forecasts: Review, Synthesis, And Suggestions for Future Research. Journal of Accounting Literature, 9:113-144.

Koch, A. S., Lefanowicz, C. E., and Robinson, J. R. (2012). Regulation FD: A Review and Synthesis of the Academic Literature. Accounting Horizons, 27:619-646.

La Porta, R., Lopez-De-Silanes, F., and Shleifer, A. (2006). What Works in Securities Laws? The Journal of Finance, 61(1):1-32.

LaCroix, K. (2020). Guest Post: "Stock Drop" Lawsuits. Available at The DEO Diary:

Lakhani, K. R., Jeppesen, L. B., Lohse, P. A., and Panetta, J. A. (2007). The value of openness in scientific problem solving. Harvard Business School Working Paper, No. 07-050.

Langevoort, D. C. (2009). Basic at twenty: Rethinking fraud on the market." Wis. L. Rev. (2009): 151. Wisconsin Law Review, 151.

Levine, M. (2014). There Will Always Be Stock-Drop Lawsuits. Available at Bloomberg: https://www.bloomberg.com/opinion/articles/2014-06-23/there-will-alwaysbe-stock-drop-lawsuits. 
Mashruwala, C., Rajgopal, S., and Shevlin, T. (2006). Why is the accrual anomaly not arbitraged away? The role of idiosyncratic risk and transaction costs. Journal of Accounting and Economics, 42(1-2):3-33.

Matsumoto, D. A. (2002). Management's Incentives to Avoid Negative Earnings Surprises. The Accounting Review, 77(3):483-514.

Mayew, W. J. (2008). Evidence of Management Discrimination Among Analysts during Earnings Conference Calls. Journal of Accounting Research, 46(3):627-659.

Naughton, J. P., Rusticus, T. O., Wang, C., and Yeung, I. (2019). Private Litigation Costs and Voluntary Disclosure: Evidence from the Morrison Ruling. The Accounting Review, $94(3): 303-327$.

Noh, S., So, E. C., and Weber, J. P. (2019). Voluntary and mandatory disclosures: Do managers view them as substitutes? Journal of Accounting and Economics, 68(1):101243.

Posner, C. S. (2019). Reg FD Enforcement Action. Harvard Law School Forum on Corporate Governance.

Posner, R. A. (2005). Judicial Behavior and Performance: An Economic Approach. Florida State University Law Review, 32:1259-1279.

Richardson, S., Teoh, S. H., and Wysocki, P. D. (2004). The Walk-down to Beatable Analyst Forecasts: The Role of Equity Issuance and Insider Trading Incentives. Contemporary Accounting Research, 21(4):885-924.

Roberts, M. R. and Whited, T. M. (2013). Endogeneity in empirical corporate finance1. Handbook of the Economics of Finance, 2:493-572.

Rogers, J. L. and Van Buskirk, A. (2009). Shareholder litigation and changes in disclosure behavior. Journal of Accounting and Economics, 47(1-2):136-156.

Rogers, J. L., Van Buskirk, A., and Zechman, S. L. C. (2011). Disclosure Tone and Shareholder Litigation. The Accounting Review, 86(6):2155-2183.

Schafhäutle, S. and Veenman, D. (2021). Crowdsourced Earnings Expectations and the Market Reaction to Street Earnings Surprises. Available at SSRN: https://ssrn.com/abstract=3444144.

SEC (2000). Final Rule: Selective Disclosure and Insider Trading.

SEC (2010). Regulation FD.

SEC (2013). SEC Says Social Media OK for Company Announcements if Investors Are Alerted.

Skinner, D. J. (1994). Why Firms Voluntarily Disclose Bad News. Journal of Accounting Research, 32(1):38-60. 
Skinner, D. J. (1997). Earnings disclosures and stockholder lawsuits. Journal of Accounting and Economics, 23(3):249-282.

Solomon, D. (2005). Court Favors Siebel In SEC's Regulation-FD Suit. The Wall Street Journal.

Solomon, D. and Soltes, E. (2015). What Are We Meeting For? The Consequences of Private Meetings with Investors. Journal of Law and Economics, 58:325-355.

Soltes, E. (2014). Private Interaction Between Firm Management and Sell-Side Analysts. Journal of Accounting Research, 52(1):245-272.

Soltes, E. (2018). What Can Managers Privately Disclose to Investors? Yale Journal on Regulation Bulletin, 36:148-169.

Stickel, S. E. (1989). The timing of and incentives for annual earnings forecasts near interim earnings announcements. Journal of Accounting and Economics, 11(2-3):275-292.

Stickel, S. E. (1992). Reputation and Performance Among Security Analysts. The Journal of Finance, 47(5):1811-1836.

Sullivan, E. and Thompson, R. B. (2004). The Supreme Court and Private Law: The Vanishing Importance for Securities and Antitrust. Emory Law Journal, 53:1571-1644.

Thompson, R. B. and Sale, H. A. (2003). Securities Fraud as Corporate Governance: Reflections upon Federalism. Vanderbilt Law Review, 56:859-910.

Unger, L. S. (2001). Special Study: Regulation Fair Disclosure Revisited.

Ventoruzzo, M. and Fedderke, J. W. (2016). Do Conservative Justices Favor Wall Street: Ideology and the Supreme Court's Securities Regulation Decisions. Florida Law Review, 67:1211-1280.

Versano, T. and Trueman, B. (2017). Expectations Management. The Accounting Review, 92(5):227-246.

Wasko, M. M. and Faraj, S. (2005). Why Should I Share? Examining Social Capital and Knowledge Contribution in Electronic Networks of Practice. MIS Quarterly, 29(1):35-57. 


\section{Appendix A. Variable definitions}

\begin{abstract}
Variable
Key variables:

$\Delta F^{\text {Analyst }}$

$\Delta F^{\text {Control }}$

Litigation_Risk

Definition

Analysts' quarter $q$ earnings forecast revision in cents per share measured at quarter $q-1$ earnings announcements. Individual analyst's revisions are computed as the $t+10$ minus $t-1$ most recent outstanding forecasts including forecasts in the 120 calendar-day window leading up to $t+10$ and $t-1$, respectively. $t$ is the day of firms' quarter $q-1$ earnings announcements. I use unadjusted earnings forecasts and subsequently adjust for stock splits using cumulative stock split factors from CRSP. (Source: I/B/E/S unadjusted detail history, CRSP)

benchmark forecasters' quarter $q$ earnings forecast revision in cents per share measured at quarter $q-1$ earnings announcements. Forecast revisions are computed as $t+10$ minus $t-1$ mean consensus forecasts, where $t$ is the day of firms' quarter $q-1$ earnings announcements. The consensus (mean) forecasts are self-constructed including each benchmark forecaster's most recent earnings forecast for quarter $q$ in the 120 calendar-day window leading up to $t+10$ and $t-1$, respectively. When benchmark forecasters issue multiple forecasts for the same firm-date-time combination, the mean of these forecasts is used. Forecasts submitted by sell-side analysts or anonymous users and forecasts flagged as unreliable from the website's management are dropped from the sample. I use unadjusted earnings forecasts and subsequently adjust for stock splits using cumulative stock split factors. (Source: Estimize)

Litigation risk is based on federal judge ideology and estimates the probability that a panel of three randomly selected judges in a given circuit decides in favor of shareholders versus the firm. Data is obtained from Huang et al. [2019] and attached to quarter $q-1$ earnings announcements. See Section 3.2 for further information and Huang et al. [2019] for a detailed description of the variable measurement.
\end{abstract}

Firm_Private_Warn

Private_Revision

Private_Warn

Firm-quarter variables:

Age

Fraction of analysts following a firm who receive bad news from managers, estimated as the sum of analysts for which Private_Warn $=1$, divided by the number of all analysts following firm $i$ at quarter $q-1$.

Extent of analysts' forecast revisions informed by private communication with managers, estimated as the difference between $\Delta F^{\text {Analyst }}$ and $\Delta F^{\text {Control }}$.

Probability that analysts' receive bad news from managers. An indicator variable equal to 1 , when $\Delta F^{\text {Analyst }}<\Delta F^{\text {Control }}$, and 0 otherwise.

Firm age at the end of fiscal quarter $q-1$, measured as the natural $\log$ of the number of years since the firm first appeared on Compustat. (Source: Compustat quarterly) 


\begin{tabular}{ll} 
Variable & Description \\
\hline Blue_State & An indicator variable identifying a state's political leaning based on the \\
& outcomes of the presidential elections in the United States measured at the \\
& end of fiscal quarter $q-1$. Blue_State is equal to 1 if a state votes for \\
& the Democratic Party, and 0 otherwise. Variables are hand-collected from \\
& wikipedia following Huang et al. [2019]. \\
& Earnings surprise in cents per share measured at quarter $q-1$ earnings \\
& announcements. ES is calculated as the difference between I/B/E/S ac- \\
& tual earnings per share and the self-constructed I/B/E/S consensus forecast, \\
& scaled by the final closing stock price from Compustat quarterly. The con- \\
& sensus (mean) forecast is constructed from individual analysts' most recent \\
& earnings forecasts made within 120 days of the announcement date. I use \\
& unadjusted earnings forecasts and actuals and subsequently adjust for stock \\
& splits using cumulative stock split factors from CRSP. (Source: I/B/E/S \\
& unadjusted detail history and actuals, CRSP, Compustat quarterly) \\
& Changes in firm quarterly earnings at quarter $q$. The difference between \\
& firm's quarterly earnings (IBQ) at quarter $q$ minus earnings (IBQ) at quarter \\
& $q-1$ and scaled by total assets at quarter $q-1$. (Source: Compustat \\
& quarterly)
\end{tabular}

Future_Loss

Firm reports quarterly loss at quarter $q$ earnings announcement. An indicator variable equal to 1 when quarterly earnings (IBQ) are negative, and 0 otherwise. (Source: Compustat quarterly)

Future_Miss

Firm misses analysts' concensus forecasts at quarter $q$ earnings announcement. An indicator variable equal to 1 when $E S<0$, and 0 otherwise. $E S$ is here measured at quarter $q$ earnings announcements.

Industry_Ret Cumulative equally-weighted monthly industry returns (RET) over the prior twelve months leading up to the end of fiscal quarter $q-1$. Industry_Ret is the average of firms' equally weighted monthly returns within a four-digit SIC code. (Source: CRSP monthly)

Inst_Hold Fraction of institutional investors (InstOwn_Perc) holding firm $i$ 's shares at the end of fiscal quarter $q-1$. (Source: Thomson/Refinitiv Institutional (13f) Holdings)

Litigation_Industry An indicator variable identifying whether a firm belongs to a high litigation risk industry at the end of fiscal quarter $q-1$, following Francis et al. [1994]. Litigious industries equal to 1 when a firm's four-digit SIC code falls in one of the following groups: biotechnology (2833-2836, 8731-8734), computers (3570-3577, 7370-7374), electronics (3600-3674), and retail (5200-5961), and 0 otherwise. (Source: Compustat quarterly)

Loss

Firm reports quarterly loss at quarter $q-1$ earnings announcements. An indicator variable equal to 1 when quarterly earnings (IBQ) are negative, and 0 otherwise. (Source: Compustat quarterly)

Market_Ret Cumulative value-weighted monthly market returns (VWRETD) over the prior twelve months leading up to the end of fiscal quarter $q-1$. (Source: CRSP monthly) 


\begin{tabular}{ll} 
Variable & Description \\
\hline$M B$ & $\begin{array}{l}\text { Market-to-book ratio at the end of fiscal quarter } q-1, \text { measured as the } \\
\text { ratio of } M V \text { to book value of common equity (CEQQ). (Source: Compustat } \\
\text { quarterly) }\end{array}$ \\
& $\begin{array}{l}\text { Firm meets or beats analysts' consensus forecast at quarter } q-1 \text { earnings } \\
\text { announcements. An indicator variable equal to } 1 \text { when } E S \geq 0, \text { and } 0 \\
\text { otherwise. }\end{array}$ \\
& $\begin{array}{l}\text { Firm size at the end of fiscal quarter } q-1 \text {, measured as the natural log of } \\
\text { the total market value of equity at the end of the fiscal quarter (PRCCQ } \times\end{array}$ \\
& CSHOQ). (Source: Compustat quarterly) \\
& $\begin{array}{l}\text { Analyst coverage measured at quarter } q-1 \text { earnings announcements. The } \\
\text { natural log of the number of analysts with an outstanding forecast of quarter } \\
q V\end{array}$ \\
& IBES unadjusted detail history)
\end{tabular}

Public_Guidance

Sales_Growth

Analyst variables:

Accuracy

Analyst_Exp

Buy

Brokersize
Firms' public guidance for quarter $q$ measured at quarter $q-1$ earnings announcements. An indicator variable equal to 1 , when firms issue public guidance at day $t$ or $t+1$, where $t$ is the day of quarter $q-1$ earnings announcements, and 0 otherwise. (Source: I/B/E/S recommendation unadjusted detail)

Sales growth at the end of fiscal quarter $q-1$, measured as the average growth of sales (SALEQ) from quarter $q-2$ to quarter $q-1$. (Source: Compustat quarterly)

Analyst's absolute forecast error measured before quarter $q-1$ earnings announcements. Forecast error is the difference between the actual earnings per share and an analyst's most recent outstanding earnings forecast. I use unadjusted earnings forecasts and actuals and subsequently adjust for stock splits using cumulative stock split factors from CRSP. (Source: IBES unadjusted detail history, CRSP)

Analyst's general working experience, measured as the difference between the date of an analyst's first appearance on I/B/E/S/ and the day of quarter $q-1$ earnings announcements, divided by 365 . (Source: IBES unadjusted detail history)

An indicator variable equal to 1 when an analyst's most recent outstanding stock recommendation before the $q-1$ earnings announcement is a buy, and 0 otherwise. (Source: IBES recommendations detail)

Number of analysts (AMASKCD) who are associated with a brokerage house (ESTIMID) in a given year before quarter $q-1$ earnings announcements. (Source: IBES recommendations detail) 


\begin{tabular}{|c|c|}
\hline Variable & Description \\
\hline Firm_Exp & $\begin{array}{l}\text { Analyst's firm experience, measured as the number of years an analyst has } \\
\text { covered a firm. Firm_Exp is the difference between the date of an analyst's } \\
\text { first recorded earnings forecast on I/B/E/S and the day of quarter } q-1 \\
\text { earnings announcements, divided by } 365 \text {. (Source: IBES unadjusted detail } \\
\text { history) }\end{array}$ \\
\hline N_Firms & $\begin{array}{l}\text { Number of firms (including firm } i \text { ) an analyst follows over quarter } q-1 \text {. } \\
\text { (Source: IBES unadjusted detail history) }\end{array}$ \\
\hline Reputation & $\begin{array}{l}\text { An indicator variable identifying prestigious brokerage houses. Reputation } \\
\text { is equal to } 1 \text { when the brokerage house (ESTIMID) is identified as one of the } \\
\text { ten largest brokerage houses in the sample, i.e., CLALEXHK, FBOSTON, } \\
\text { FRCLAYSC, GOLDMAN, JEFFEREG, JPMORGAN, LAWRENCE, } \\
\text { MACQUARI, MERRILL, and MORGAN, and } 0 \text { otherwise. (Source: IBES } \\
\text { recommendations detail) }\end{array}$ \\
\hline Sell & $\begin{array}{l}\text { An indicator variable equal to } 1 \text { when an analyst's most recent outstanding } \\
\text { stock recommendation before the } q-1 \text { earnings announcement is a sell, and } \\
0 \text { otherwise. (Source: IBES recommendations detail) }\end{array}$ \\
\hline Strong_Buy & $\begin{array}{l}\text { An indicator variable equal to } 1 \text { when an analyst's most recent outstanding } \\
\text { stock recommendation prior to the } q-1 \text { earnings announcement is a strong } \\
\text { buy, and } 0 \text { otherwise. (Source: IBES recommendations detail) }\end{array}$ \\
\hline Strong_Sell & $\begin{array}{l}\text { An indicator variable equal to } 1 \text { when an analyst's most recent outstanding } \\
\text { stock recommendation before the } q-1 \text { earnings announcement is a strong } \\
\text { sell, and } 0 \text { otherwise. (Source: IBES recommendations detail) }\end{array}$ \\
\hline
\end{tabular}




\section{Appendix B. SEC Enforcement Actions for Regulation Fair Disclosure Violations}

Notes: This table provides an overview of SEC enforcement actions against firms ("issuer") and persons who act on behalf of the firm ("individual") because of violations of Reg FD regulation. The first column presents the date of the SEC's enforcement actions ("date"). The second and third column report the issuer or individual against which/whom claims are made. The fourth column reports whether the case is proceeded in federal court or in front of an administrative agency ("proceeding"). When the case is pursued in court, I report the federal district. The fifth column summarizes the SEC's main claim made against the issuer or person ("claim") and the sixth column summarizes the SEC's enforcement actions. Even when the SEC does not require firms to pay a penalty, firms would receive a cease-and-desist order which requires the issuer or individual to immediately stop violating the securities law. Mostly, firms settle with the SEC directly and cases are not heard in front of a court.

\begin{tabular}{|c|c|c|c|c|c|}
\hline Date & Issuer & Individual & Proceeding & Claim & Enforcement \\
\hline Nov/02 & $\begin{array}{l}\text { Raytheon } \\
\text { Company }\end{array}$ & F. A. Caine (CFO) & administrative & $\begin{array}{l}\text { Selectively disclosed material } \\
\text { information to research } \\
\text { analysts during private phone } \\
\text { calls }\end{array}$ & $\$ 0$ \\
\hline Nov/02 & $\begin{array}{c}\text { Siebel } \\
\text { Systems, Inc. }\end{array}$ & - & $\begin{array}{c}\text { judicial (District of } \\
\text { Columbia) }\end{array}$ & $\begin{array}{l}\text { Selectively disclosed material } \\
\text { information during a private } \\
\text { technology conference }\end{array}$ & $\$ 250 \mathrm{~K}$ \\
\hline Nov/02 & Motorola, Inc. & - & - & $\begin{array}{l}\text { Selectively disclosed material } \\
\text { information to analysts } \\
\text { during private phone calls }\end{array}$ & $\begin{array}{l}\$ 0 \text { (sole report of } \\
\text { investigation to remind } \\
\text { firms of Reg FD) }\end{array}$ \\
\hline Sep/03 & $\begin{array}{l}\text { Schering- } \\
\text { Plough } \\
\text { Corporation }\end{array}$ & R. J. Kogan (CEO) & administrative & $\begin{array}{l}\text { Selectively disclosed material } \\
\text { information to investors and } \\
\text { research analysts during } \\
\text { private events }\end{array}$ & $\begin{array}{c}\$ 1 \mathrm{M}(\text { firm }), \$ 50 \mathrm{~K} \\
(\mathrm{CEO})\end{array}$ \\
\hline
\end{tabular}




\begin{tabular}{|c|c|c|c|c|c|}
\hline Sep/05 & $\begin{array}{c}\text { Siebel } \\
\text { Systems, Inc. }\end{array}$ & $\begin{array}{l}\text { K. Goldman (CFO), } \\
\text { M. H. (Senior Vice } \\
\text { President) }\end{array}$ & $\begin{array}{l}\text { judicial (Southern } \\
\text { District of New York) }\end{array}$ & $\begin{array}{l}\text { Selectively disclosed material } \\
\text { information to investors and } \\
\text { research analysts during } \\
\text { private events }\end{array}$ & $\$ 0$ (dismissed by court) \\
\hline Sep/07 & $\begin{array}{c}\text { Electronic } \\
\text { Data Systems } \\
\text { Corporation }\end{array}$ & - & administrative & $\begin{array}{l}\text { Selectively disclosed material } \\
\text { information to analysts }\end{array}$ & $\$ 0$ \\
\hline Sep/09 & - & $\begin{array}{l}\text { C. A. Black (CFO, } \\
\text { American Commerical } \\
\text { Lines, Inc.) }\end{array}$ & administrative & $\begin{array}{l}\text { Selectively disclosed private } \\
\text { guidance to analysts via email }\end{array}$ & $\$ 25 \mathrm{~K}$ \\
\hline Mar/10 & Presstek, Inc. & E. J. Marino (CEO) & administrative & $\begin{array}{l}\text { Selectively disclosed material } \\
\text { information to investors }\end{array}$ & $\begin{array}{l}\$ 400 \mathrm{~K}(\text { firm }), \$ 50 \mathrm{~K} \\
(\mathrm{CEO})\end{array}$ \\
\hline Oct $/ 10$ & $\begin{array}{l}\text { Office Depot, } \\
\text { Inc. }\end{array}$ & $\begin{array}{l}\text { S. A. Odland (CEO), } \\
\text { P. A. McKay (CFO) }\end{array}$ & administrative & $\begin{array}{l}\text { Selectively disclosed private } \\
\text { guidance to investors and } \\
\text { research analysts during } \\
\text { private events }\end{array}$ & $\begin{array}{l}\$ 1 \mathrm{M}(\text { firm }), \$ 50 \mathrm{~K} \\
(\mathrm{CEO} \text { and } \mathrm{CFO})\end{array}$ \\
\hline Nov/11 & $\begin{array}{l}\text { Fifth Third } \\
\text { Bancorp }\end{array}$ & - & administrative & $\begin{array}{l}\text { Selectively disclosed private } \\
\text { information to investors } \\
\text { about redemption of } \\
\text { securities }\end{array}$ & $\$ 0$ \\
\hline Apr/13 & Netflix, Inc. & R. Hastings (CEO) & administrative & $\begin{array}{l}\text { Posting material information } \\
\text { on Hastings' personal } \\
\text { facebook webpage }\end{array}$ & $\$ 0$ (SEC drops charges) \\
\hline Sep/13 & - & $\begin{array}{l}\text { L. D. Polizzotto (head } \\
\text { of investor relation, } \\
\text { First Solar, Inc.) }\end{array}$ & administrative & $\begin{array}{l}\text { Selectively disclosed material } \\
\text { information to investors and } \\
\text { research analysts }\end{array}$ & $\$ 50 \mathrm{~K}$ \\
\hline Sep/18 & Tesla, Inc. & E. Musk (CEO) & $\begin{array}{l}\text { judicial (Southern } \\
\text { District of New York) }\end{array}$ & $\begin{array}{l}\text { Posting material, misleading } \\
\text { and false, information on } \\
\text { Musk's twitter account }\end{array}$ & $\begin{array}{l}\$ 20 \mathrm{M}(\text { firm }), \$ 20 \mathrm{M} \\
(\mathrm{CEO})\end{array}$ \\
\hline $\mathrm{Aug} / 19$ & TherapeuticsMD & - & administrative & $\begin{array}{l}\text { Selectively disclosed material } \\
\text { information to research } \\
\text { analysts in private messages }\end{array}$ & $\$ 200 \mathrm{~K}$ \\
\hline Mar/21 & AT\&T, Inc. & $\begin{array}{l}\text { C. C. Womack; K. D. } \\
\text { Evans; M. J. Black } \\
\text { (investor relation) }\end{array}$ & $\begin{array}{l}\text { judicial (Southern } \\
\text { District of New York) }\end{array}$ & $\begin{array}{c}\text { Selectively disclosed material } \\
\text { information to research } \\
\text { analysts during private phone } \\
\text { calls }\end{array}$ & Ongoing \\
\hline
\end{tabular}




\section{Appendix C. Overview of benchmark forecasters' background information}

Notes: This figure provides an overview of the full sample of unique users, referred to as benchmark forecasters, in the Estimize sample over the period from 2021Q1 to 2019Q2. On Estimize.com, new users can identify themselves as financial professional or non-financial professional analysts and further specify their professional profiles. I refer to anonymous analysts when a user's profession is unknown, i.e., not disclosed on the website. To select my control group, I eliminate anonymous and sell-side analysts, highlighted in red. I retain buy-side and independent analysts as well as non-financial professional analysts. It is important to note that this is the full sample of benchmark forecasters before applying strict sample selection criteria to the data. This means that the final group of benchmark forecasters, which submits quarter $q$ forecasts around the days of quarter $q-1$ earnings announcements, consists of $10 \%$ buy-side analysts, $12 \%$ independent analysts, and $78 \%$ non-professional benchmark forecasters (5,157 benchmark forecasters). Within the group of buy-side analysts, hedge fund (197) and asset manager (169) are the most frequently identified professions. Within the group of non-professional benchmark forecasters, most users are employed in Information Technology (1,025), Software (340),

IT Services (289), and Internet Software and Services (232). 


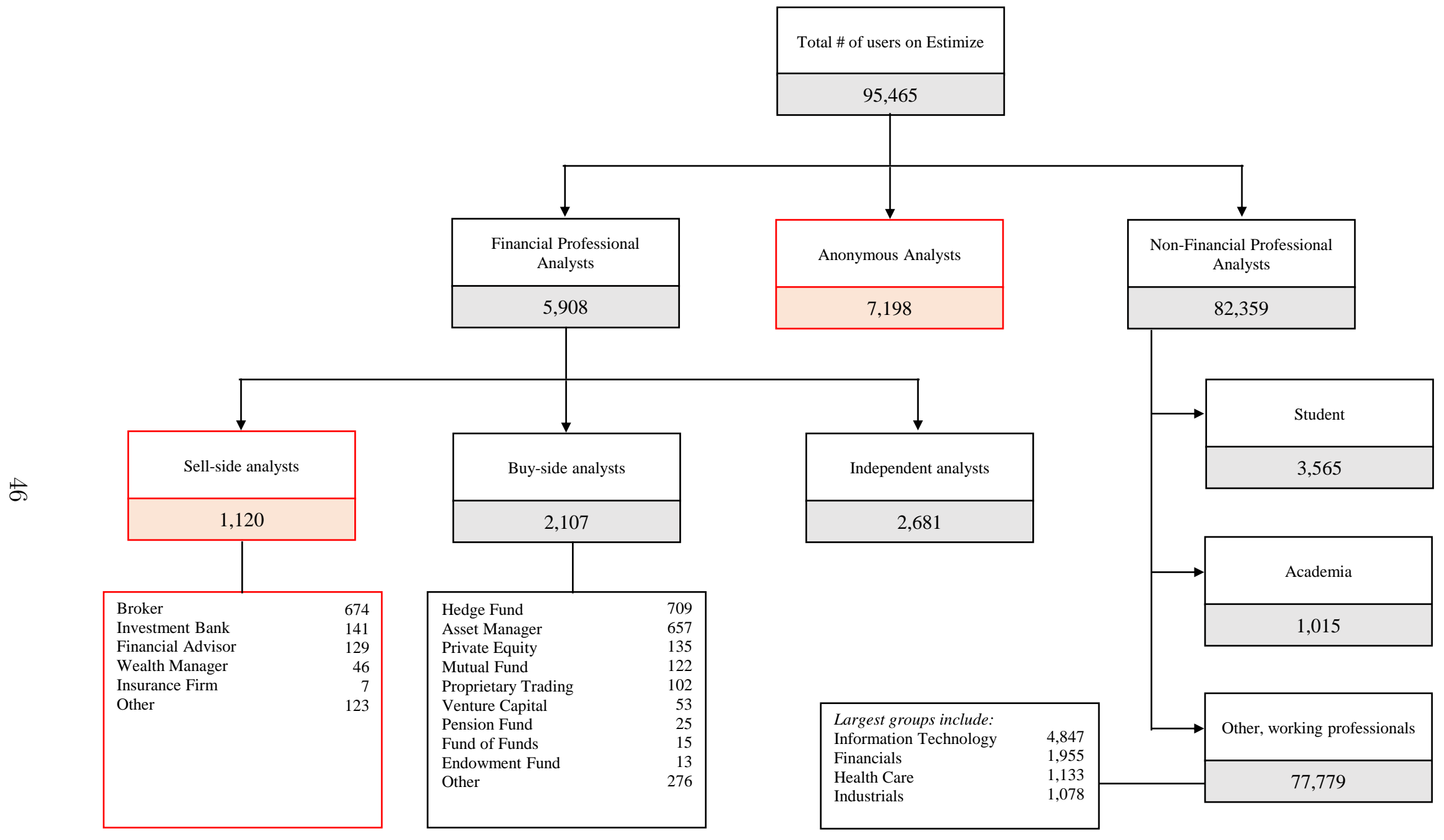




\section{Figure 1}

\section{Setting and timeline}

This figure displays a timeline including the prior- and current-quarter earnings announcements which correspond to the sample selection procedures and calculation of key variables. In essence, this paper focuses on quarter $q$ forecasts that are revised around the days of firms' quarter $q-1$ earnings announcements to estimate the likelihood that analysts' forecast revisions are due to private communication with managers. To hold constant the extent of analysts' forecast revisions due to public information, I benchmark analysts' forecast revisions to a control group of benchmark forecasters. The empirical strategy is motivated by Schafhäutle and Veenman [2021], who find that analysts strongly revise quarter $q$ earnings forecasts around the days of quarter $q-1$ earnings announcements, which is when manager-analyst private meetings peak (Soltes [2014]). The combined factors that analysts update earnings forecasts for quarter $q$ at quarter $q-1$ using public (e.g., 10-K, 10-Q, management forecasts) and private (e.g., private meetings with managers) information and benchmark forecasters only observe publicly available information lies at the heart of the empirical strategy to estimate managers' private information flows. Appendix A summarizes the variable construction in detail.

Private_Revision

The difference between analysts' and benchmark forecasters' earnings forecast revisions for quarter $q$ over the days of quarter $q-l$ EA.

Private_Warn

Firm_Private_Warn

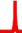

Firm-Quarter

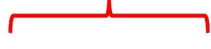

Firm-Quarter
$\begin{aligned} & \text { The analyst updates earnings } \\ & \text { forecasts for the subsequent } \\ & \text { quarter using public and } \\ & \text { private information. }\end{aligned}$
EA(q)
$\begin{aligned} & \text { The manager reports earnings for } \\ & \text { the firm and engages in private } \\ & \text { conversations with analysts } \\ & \text { shortly after the news release. }\end{aligned}$




\section{Figure 2}

\section{Median earnings forecast revisions in event time}

This figure presents earnings forecast revisions of analysts and benchmark forecasters over the days around prior-quarter earnings announcements $(t=0)$. On each of the event days $[-3,10]$ around firms' prior-quarter earnings announcements, I first compute analysts' and benchmark forecasters' median consensus earnings forecasts per firm-quarter and scaled by prior-quarter closing price. Appendix A summarizes the variable construction in detail (see $\Delta F^{\text {Analyst }}$ and $\Delta F^{\text {Control }}$ ). All $t$ consensus forecasts are constructed over the $[t-120, t]$ forecasting horizon. For instance, on day -3 , the consensus forecast is constructed from forecasts issued in the $[-123,-3]$ window. I then calculate sample median consensus forecasts. Second, I calculate changes in analysts' and benchmark forecasters' median consensus forecasts between $t-1$ and $t$ to illustrate the groups' daily median earnings forecast revisions. The solid blue line depicts analysts' median earnings forecast revisions and the dashed pink line depicts benchmark forecasters' median earnings forecast revisions during the $[-3,10]$ forecasting horizon. The $\mathrm{x}$-axis denotes the event-days (calendar days) relative to firms' prior-quarter earnings announcements. The y-axis denotes the median earnings forecast revision scaled by price in cents per share. Negative values illustrate downward revisions and zero values illustrate no revision in earnings forecasts.

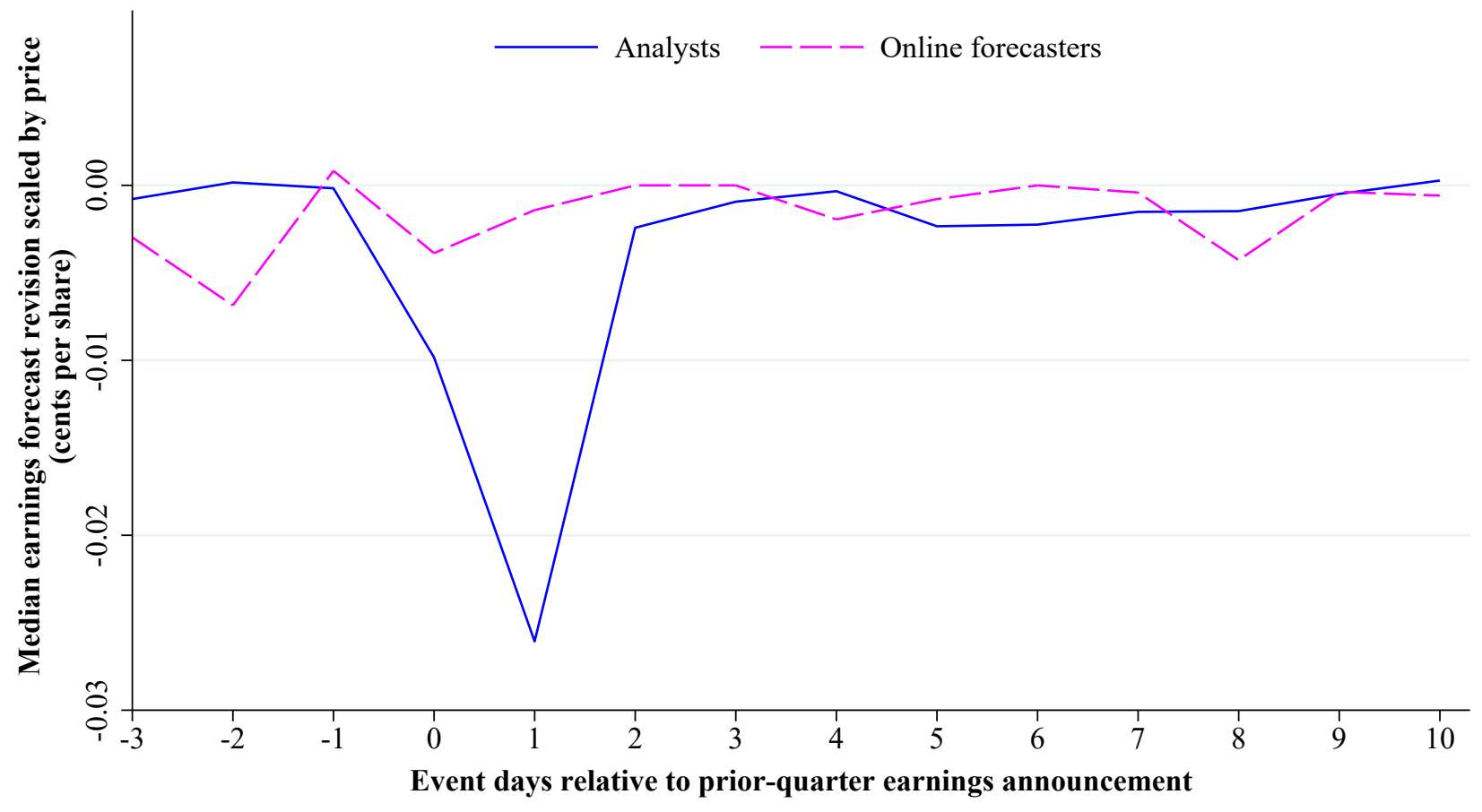




\section{Figure 3}

Distribution of firm's propensity to privately leak bad news to analysts

This figure presents the frequency distribution of my measure of firms' propensity to privately communicate with analysts about bad news. Firm_Private_Warn is measured based on the differential forecasting behavior between sell-side analysts and benchmark forecasters. The x-axis reflects the fraction of analysts following a firm who are likely to receive private earnings warnings from managers. The variable is constructed as such that a higher value indicates that firms' propensity to leak bad news to the majority of analysts increases. Appendix A summarizes the variable construction in detail.

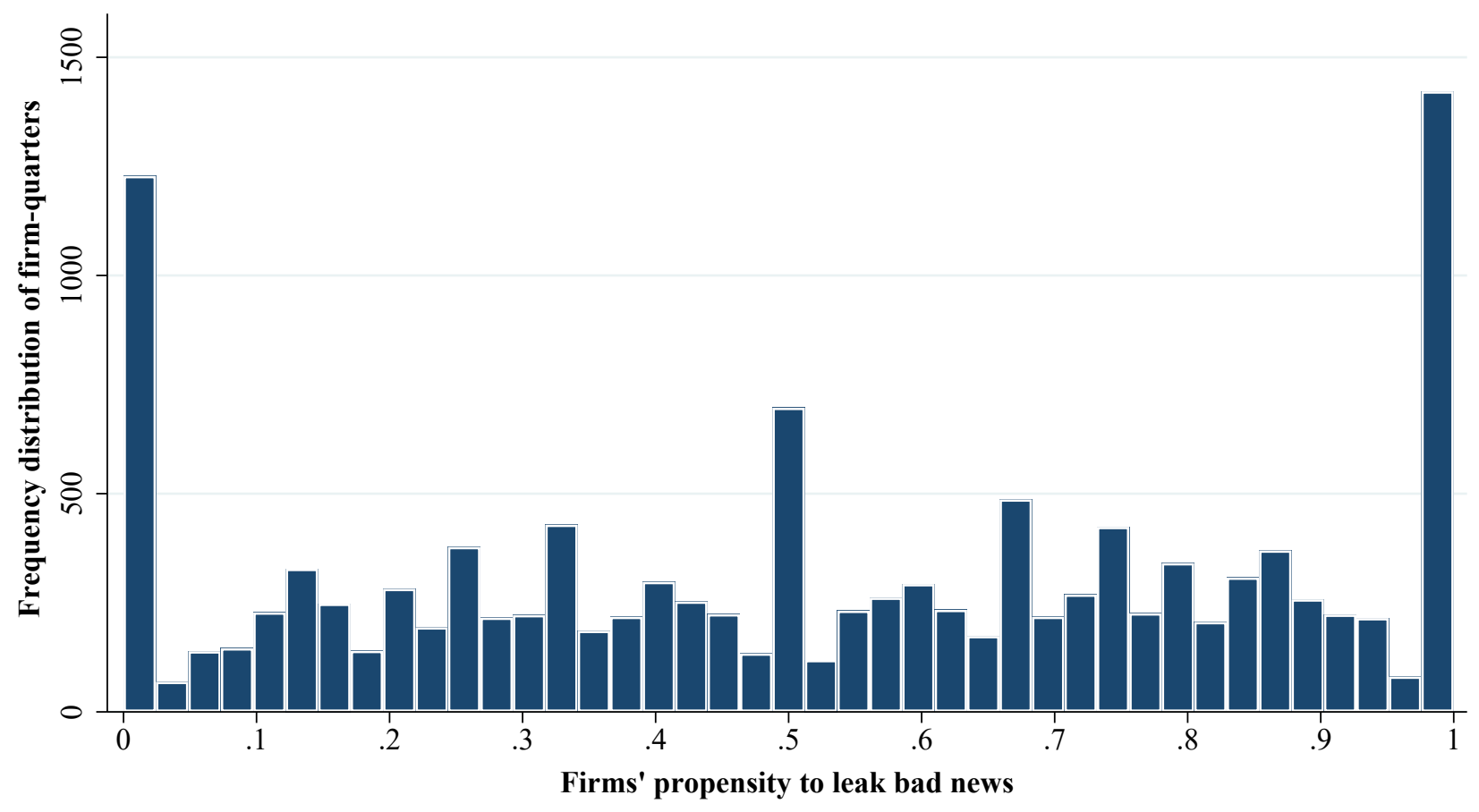




\section{Figure 4}

\section{Time trend of expected shareholder litigation risk}

This figure illustrates the annual distribution of shareholder litigation risk, i.e., judge ideology, from 2012 to 2019 using data from Huang et al. [2019]. Litigation risk is estimated as the probability that a panel of three randomly selected judges in a given circuit is dominated by liberal judges. A panel dominated by liberal judges is more likely to decide in favor of shareholders rather than the firm. The y-axis displays the probability that the panel of three randomly selected judges consists of at least two liberal judges, i.e., appointed by a Democratic president. A higher value of judge ideology indicates that the federal circuit court is more liberal. The distribution of judge ideology is illustrated using boxplots, which highlight the minimum values, 25 th percentiles, 50 th percentiles, 75 th percentiles, and maximum values. The red dotted line displays the mean of judge ideology over time. Appendix A summarizes the variable construction in detail. For more information on the construction of judge ideology see Huang et al. [2019].

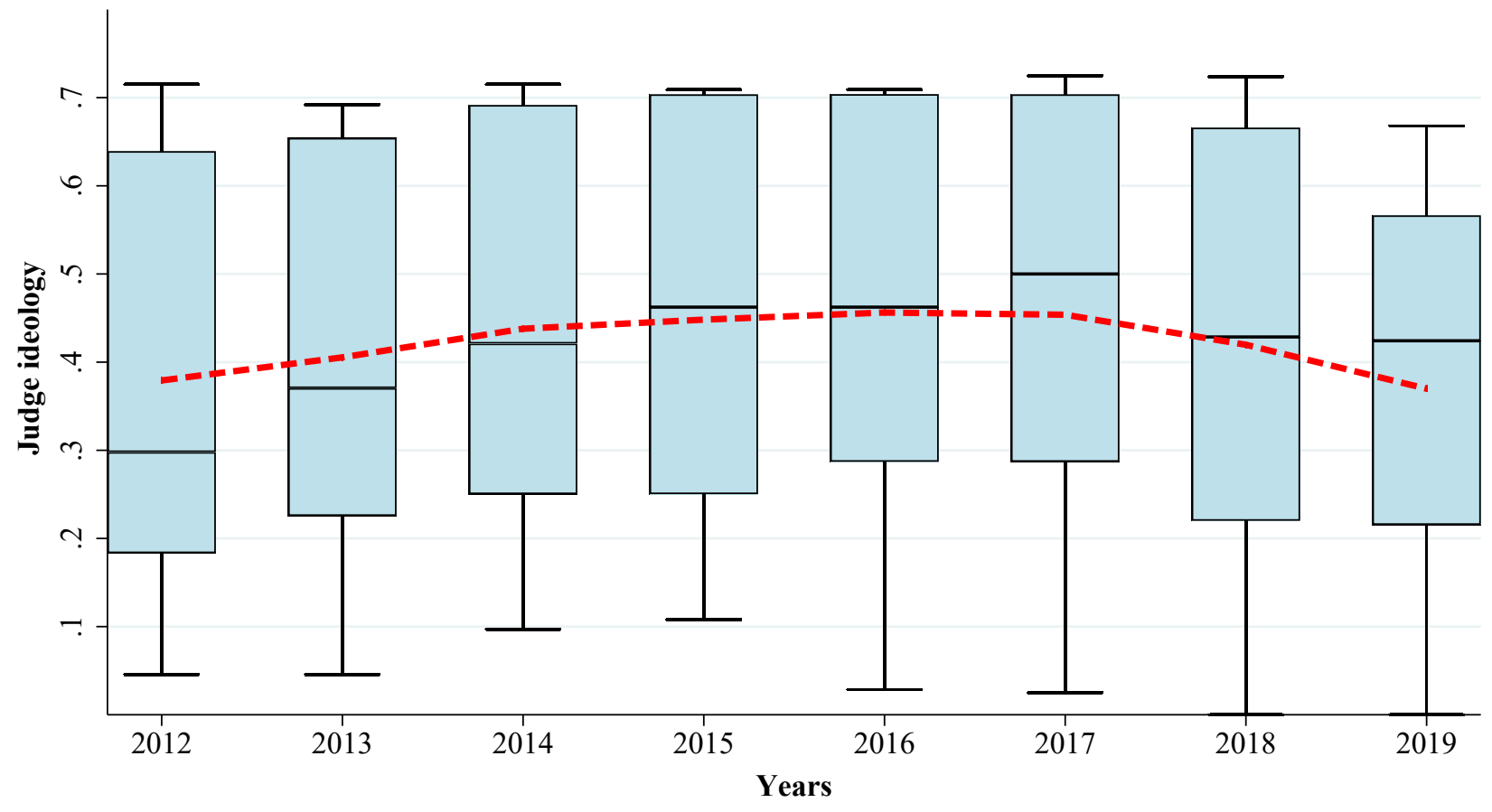




\section{Table 1}

\section{Sample selection}

Panel A: Sample selection of analysts' forecast revisions

Analyst-firm-

quarter

Analyst-firm-quarter observations from I/B/E/S unadjusted detail history from

936,730

2012Q1-2019Q2 using the following criteria:

(1) Availability of prior- and current-quarter reporting dates across CRSP-Compustat Merged, I/B/E/S, and Estimize

(2) Firm reports in US Dollars, reported earnings and estimates are adjusted for stock splits using split adjustment factors from CRSP

(3) Analyst is identifiable with unique analyst code

Less: Analyst has no outstanding quarter $q$ forecast over the $[t-1 ; t-120]$ window,

$-193,474$

where $\mathrm{t}$ is the day of quarter $q-1$ earnings release

Less: Analyst has no outstanding quarter $q$ forecast over the $[t+10 ; t-109]$ window, where $\mathrm{t}$ is the day of quarter $q-1$ earnings release

\begin{tabular}{lr} 
Final I/B/E/S forecast revision sample & 739,018 \\
Less: Missing analyst controls & $-152,881$ \\
Less: Missing control sample forecast revisions & $-454,352$ \\
\hline Final sample of analysts' forecast revisions used in analyst-level tests & 131,785 \\
\hline
\end{tabular}

Panel B: Sample selection of the control group's forecast revisions

Forecaster-

firm-quarter

Forecaster-firm-quarter observations from contributors on Estimize from 2012Q1873,271 2019Q2 using the following criteria:

(1) Firm can be linked to common firm identifiers on CRSP, Compustat, and I/B/E/S

(2) Availability of prior- and current-quarter reporting dates across CRSP-Compustat Merged, I/B/E/S, and Estimize

(3) Reported earnings and estimates are adjusted for stock splits using split adjustment factors from Estimize

Less: Forecasts that are flagged by Estimize and considered unreliable

Less: Data errors, i.e., forecasts recorded after the reporting date

Less: Forecasts contributed by sell-side analysts or anonymous contributors

Less: Contributor has no outstanding quarter $q$ forecast over the $[t-1 ; t-120]$ window, $-682,154$ where $\mathrm{t}$ is the day of quarter $q-1$ earnings release

Less: Contributor has no outstanding quarter $q$ forecast over the $[t+10 ; t-109]$ window, where $\mathrm{t}$ is the day of quarter $q-1$ earnings release 
Panel C: Main sample selection

\begin{tabular}{lrr}
\hline & $\begin{array}{c}\text { Firm- } \\
\text { quarter }\end{array}$ & Firms \\
\hline Unique firm-quarter observations obtained from CRSP-Compustat & 173,901 & 7,934 \\
Merged for the period from 2012Q1-2019Q2 & & \\
Less: Firms with missing key variables & $-22,554$ & -794 \\
Less: Firms not listed on NYSE, AMEX, or NASDAQ & $-1,724$ & -10 \\
Less: Firms with missing analyst forecast revisions & $-46,276$ & $-1,611$ \\
Less: Firms with missing control group forecast revisions & $-88,508$ & $-3,599$ \\
Less: Firms with missing litigation risk proxy & $-1,054$ & -136 \\
Less: Firms with missing control variables & $-1,167$ & -144 \\
\hline Final firm-quarter sample & 12,618 & 1,640 \\
\hline
\end{tabular}

Notes: Panel A presents the sample selection of I/B/E/S analysts' forecast revisions. Panel B presents the sample selection of the control group's forecast revisions. The control group's earnings forecast data is obtained from Estimize, an online financial forecasting platform, dating back to 2012Q1. Underlying the construction of analysts' and the control group of benchmark forecasters' earnings forecast revisions are precisely identified reporting date variables. I identify earnings reporting dates based on identically recorded date variables across all three and at least two data sets using CRSP-Compustat, Estimize, and I/B/E/S. For the ten firm-quarter observations that have no overlapping reporting dates, I hand-collect the precise reporting date from firms' press releases and websites. Panel $\mathrm{C}$ presents the sample selection of the final firm-quarter sample with fiscal quarters from 2012Q1-2019Q4. 
Table 2

Descriptive statistics

Panel A: Descriptive statistics firm-quarter sample

\begin{tabular}{|c|c|c|c|c|c|c|}
\hline & $\mathrm{N}$ & Mean & $\mathrm{SD}$ & Min & Median & Max \\
\hline \multicolumn{7}{|l|}{ Key variables: } \\
\hline$\overline{\Delta F^{\text {Analyst }}}$ & 12,618 & -0.0279 & 0.1274 & -0.62 & 0 & 0.38 \\
\hline$\Delta F^{\text {Control }}$ & 12,618 & -0.0049 & 0.0429 & -0.2313 & 0 & 0.1469 \\
\hline Private_Revision & 12,618 & -0.0235 & 0.1257 & -0.59 & -0.0033 & 0.3866 \\
\hline Firm_Private_Warn & 12,618 & 0.5233 & 0.3222 & 0 & 0.5263 & 1 \\
\hline Litigation_Risk & 12,618 & 0.4676 & 0.2269 & 0 & 0.5 & 0.7249 \\
\hline \multicolumn{7}{|c|}{ Firm and market controls: } \\
\hline Public_Guidance & 12,618 & 0.2571 & 0.437 & 0 & 0 & 1 \\
\hline$E S$ & 12,618 & 0.0526 & 0.1467 & -0.4331 & 0.0322 & 0.7413 \\
\hline Loss & 12,618 & 0.2384 & 0.4261 & 0 & 0 & 1 \\
\hline$M B E$ & 12,618 & 0.7581 & 0.4282 & 0 & 1 & 1 \\
\hline$M V$ (in million USD) & 12,618 & $25,531.69$ & $54,118.37$ & 150.7 & $6,040.65$ & $346,898.2$ \\
\hline$M B$ & 12,618 & 4.8432 & 11.2712 & -44.706 & 3.1636 & 69.2381 \\
\hline Sales_Growth & 12,618 & 0.0355 & 0.1723 & -0.4595 & 0.0245 & 0.8806 \\
\hline$N$ & 12,618 & 12.4282 & 7.4809 & 1 & 11 & 34 \\
\hline Inst_Hold & 12,618 & 0.5413 & 0.4015 & 0 & 0.7211 & 1 \\
\hline Age & 12,618 & 27.3632 & 16.2231 & 4 & 24 & 58 \\
\hline Industry_Ret & 12,618 & 0.1152 & 0.2429 & -0.4885 & 0.1092 & 0.9111 \\
\hline Market_Ret & 12,618 & 0.1275 & 0.0804 & -0.0631 & 0.1477 & 0.2636 \\
\hline Litigation_Industry & 12,618 & 0.4405 & 0.4965 & 0 & 0 & 1 \\
\hline Blue_State & 12,618 & 0.6357 & 0.4813 & 0 & 1 & 1 \\
\hline
\end{tabular}

Panel B: Descriptive statistics for low vs. high litigation risk sample

\begin{tabular}{|c|c|c|c|c|c|c|}
\hline & \multicolumn{2}{|c|}{ Litgation_Risk $<=.5$} & \multicolumn{2}{|c|}{ Litgation_Risk $>.5$} & \multirow[b]{2}{*}{ Mean diff. } & \multirow[b]{2}{*}{ t-stat. } \\
\hline & $\mathrm{N}$ & Mean & $\mathrm{N}$ & Mean & & \\
\hline Firm_Private_Warn & 6,600 & 0.5140 & 6,018 & 0.5336 & -0.0196 & $(2.35)^{* *}$ \\
\hline Public_Guidance & 6,600 & 0.2352 & 6,018 & 0.2811 & -0.0460 & $(1.97)^{*}$ \\
\hline$E S$ & 6,600 & 0.0454 & 6,018 & 0.0604 & -0.0150 & $(3.18)^{* * *}$ \\
\hline Loss & 6,600 & 0.2076 & 6,018 & 0.2721 & -0.0646 & $(3.10)^{* * *}$ \\
\hline$M B E$ & 6,600 & 0.7403 & 6,018 & 0.7777 & -0.0374 & $(3.14)^{* * *}$ \\
\hline$M V$ (in million USD) & 6,600 & $20,415.5$ & 6,018 & $31,141.7$ & $-10,726.2$ & $(2.85)^{* * *}$ \\
\hline$M B$ & 6,600 & 3.7695 & 6,018 & 6.0206 & -2.2511 & $(5.24)^{* * *}$ \\
\hline Sales_Growth & 6,600 & 0.0326 & 6,018 & 0.0385 & -0.0059 & $(0.95)$ \\
\hline$N$ & 6,600 & 12.0667 & 6,018 & 12.8247 & -0.7580 & $(1.55)$ \\
\hline Inst_Hold & 6,600 & 0.5505 & 6,018 & 0.5311 & 0.0194 & $(-1.15)$ \\
\hline Age & 6,600 & 30.4303 & 6,018 & 24 & 6.4303 & $(-6.79)^{* * *}$ \\
\hline Industry_Ret & 6,600 & 0.1066 & 6,018 & 0.1247 & -0.0181 & $(1.71)^{*}$ \\
\hline Litigation_Industry & 6,600 & 0.3674 & 6,018 & 0.5207 & -0.1533 & $(5.15)^{* * *}$ \\
\hline Blue_State & 6,600 & 0.4141 & 6,018 & 0.8787 & -0.4646 & $(15.51)^{* * *}$ \\
\hline
\end{tabular}


Panel C: Descriptive statistics analyst-level sample

\begin{tabular}{|c|c|c|c|c|c|c|}
\hline & $\mathrm{N}$ & Mean & $\mathrm{SD}$ & Min & Median & Max \\
\hline \multicolumn{7}{|l|}{ Key variables: } \\
\hline$\overline{\text {Private_Warn }}$ & 131,785 & 0.5260 & 0.4993 & 0 & 1 & 1 \\
\hline Strong_Buy & 131,785 & 0.1955 & 0.3966 & 0 & 0 & 1 \\
\hline Buy & 131,785 & 0.3389 & 0.4733 & 0 & 0 & 1 \\
\hline Sell & 131,785 & 0.0094 & 0.0967 & 0 & 0 & 1 \\
\hline Strong_Sell & 131,785 & 0.0497 & 0.2174 & 0 & 0 & 1 \\
\hline \multicolumn{7}{|c|}{ Analyst controls: } \\
\hline Accuracy & 131,785 & 0.1133 & 0.1697 & 0 & 0.06 & 1.1 \\
\hline Brokersize & 131,785 & 101.47 & 101.75 & 2 & 55 & 329 \\
\hline Firm_Exp & 131,785 & 5.82 & 5.3 & 0 & 4.28 & 24.53 \\
\hline Analyst_Exp & 131,785 & 13.24 & 8.41 & 0.2521 & 12.18 & 32.59 \\
\hline N_Firms & 131,785 & 14 & 7.71 & 1 & 14 & 37 \\
\hline Reputation & 131,785 & 0.3296 & 0.4701 & 0 & 0 & 1 \\
\hline
\end{tabular}

Panel D: Sample distribution across industries

\begin{tabular}{|c|c|c|c|}
\hline & $\mathrm{N}$ & $\%$ & $\begin{array}{r}\text { Mean } \\
\text { Comm. }\end{array}$ \\
\hline Consumer Non-Durables & 743 & 5.89 & 0.6395 \\
\hline Consumer Durables & 313 & 2.48 & 0.5523 \\
\hline Manufacturing & 1,072 & 8.50 & 0.5494 \\
\hline Oil, Gas, and Coal Extraction & 711 & 5.63 & 0.4295 \\
\hline Chemicals and Allied Products & 203 & 1.61 & 0.5565 \\
\hline Business Equipment & 3,921 & 31.07 & 0.5202 \\
\hline Telephone and Television Transmission & 329 & 2.61 & 0.5228 \\
\hline Utilities & 209 & 1.66 & 0.3922 \\
\hline Wholesale, Retail, and some Services & 1,596 & 12.65 & 0.5421 \\
\hline Healthcare, Medical Equipment, and Drugs & 1,194 & 9.46 & 0.4900 \\
\hline Finance & 938 & 7.43 & 0.4968 \\
\hline Other & 1,389 & 11.01 & 0.5312 \\
\hline Total & 12,618 & 100 & 0.5233 \\
\hline
\end{tabular}

Notes: Panel A presents descriptive statistics on the variables used in the firm-quarter analysis. Panel B present descriptive statistics for the sample split into low (Litigation_Risk $<=.5$ ) and high (Litigation_Risk $>.5$ ) litigation risk. The differences in the sample means are constructed and t-statistics are presented in parentheses. The ${ }^{*}, * *, * * *$ reflect two-tailed significance levels at the $0.1,0.05$, and 0.01 , respectively. T-statistics are corrected for firm and year-quarter clustering in the standard errors. Panel $\mathrm{C}$ presents descriptive statistics on the variables used in the analyst-level test (see Table 3). For brevity, Panel $\mathrm{C}$ presents the dependent and analyst-level variables but excludes other control variables as displayed in Panel A. All continuous variables are winsorized at the 1st and 99th percentiles of their distributions. For presentation purposes, the raw versions of variables are displayed, such that $E S$ is not scaled by stock price and $M V, N$, and Age are not log-transformed. Panel D present the sample distribution across industries. Appendix A summarizes the variable definitions and constructions in detail. 
Table 3

Do analysts with preferred access to managers receive private earnings warnings?

\begin{tabular}{|c|c|c|}
\hline & Private_Warn & Private_Warn \\
\hline \multicolumn{3}{|l|}{ Access to managers: } \\
\hline$\overline{\text { Strong_Buy }}$ & $\begin{array}{r}0.034 \\
(8.08)^{* * *}\end{array}$ & $\begin{array}{r}0.034 \\
(7.69)^{* * *}\end{array}$ \\
\hline Buy & $\begin{array}{r}0.026 \\
(7.94)^{* * *}\end{array}$ & $\begin{array}{r}0.025 \\
(7.53)^{* * *}\end{array}$ \\
\hline Sell & $\begin{array}{r}-0.060 \\
(-4.30)^{* * *}\end{array}$ & $\begin{array}{r}-0.063 \\
(-4.22)^{* * *}\end{array}$ \\
\hline Strong_Sell & $\begin{array}{r}-0.038 \\
(-6.67)^{* * *}\end{array}$ & $\begin{array}{r}-0.037 \\
(-5.48)^{* * *}\end{array}$ \\
\hline \multicolumn{3}{|l|}{ Analyst and firm controls: } \\
\hline$\overline{\text { Accuracy }}$ & $\begin{array}{r}-0.045 \\
(-6.47)^{* * *}\end{array}$ & $\begin{array}{l}-0.019 \\
(-1.50)\end{array}$ \\
\hline Brokersize & $\begin{array}{r}0.034 \\
(4.18)^{* * *}\end{array}$ & $\begin{array}{r}0.034 \\
(4.26)^{* * *}\end{array}$ \\
\hline Firm_Exp & $\begin{array}{r}0.001 \\
(0.24)\end{array}$ & $\begin{array}{r}0.002 \\
(0.27)\end{array}$ \\
\hline Analyst_Exp & $\begin{array}{l}-0.004 \\
(-0.63)\end{array}$ & $\begin{array}{l}-0.006 \\
(-0.95)\end{array}$ \\
\hline N_Firms & $\begin{array}{r}0.031 \\
(4.65)^{* * *}\end{array}$ & $\begin{array}{r}0.038 \\
(5.75)^{* * *}\end{array}$ \\
\hline Reputation & $\begin{array}{l}-0.007 \\
(-1.08)\end{array}$ & $\begin{array}{l}-0.007 \\
(-1.30)\end{array}$ \\
\hline Public_Guidance & & $\begin{array}{r}0.010 \\
(0.83)\end{array}$ \\
\hline$E S$ & & $\begin{array}{r}-0.118 \\
(-5.95)^{* * *}\end{array}$ \\
\hline Loss & & $\begin{array}{r}-0.019 \\
(-1.60)\end{array}$ \\
\hline$M B E$ & & $\begin{array}{r}-0.041 \\
(-2.80)^{* * *}\end{array}$ \\
\hline Inst_Hold & & $\begin{array}{r}0.031 \\
(1.78)^{*}\end{array}$ \\
\hline 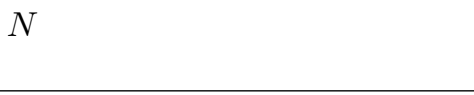 & & $\begin{array}{r}0.006 \\
(0.25) \\
\end{array}$ \\
\hline Firm-year-quarter fixed effects & YES & $\mathrm{NO}$ \\
\hline Firm fixed effects & $\mathrm{NO}$ & YES \\
\hline Year-quarter fixed effects & NO & YES \\
\hline $\mathrm{n}$ & 131,785 & 131,785 \\
\hline Adjusted $R^{2}$ & $32.7 \%$ & $8.2 \%$ \\
\hline
\end{tabular}

Notes: This Table estimates the relation between analysts' preferred access to managers and the probability that analysts receive private earnings warnings from managers using linear probability models (estimated using OLS). The dependent variable is Private_Warn and the key independent variables are Strong_Buy, Buy, Sell, and Strong_Sell. Appendix A summarizes the variable definitions and constructions in detail. All continuous variables are ranked to quarterly deciles and subsequently transformed to a $[-0.5,0.5]$ scale. The first column presents the results including firm-year-quarter fixed effects and the second column including firm and year-quarter fixed effects and additional firm controls. Standard errors are adjusted for heteroskedasticity and clustered by analyst and year-quarter. Coefficient estimates and t-statistics are presented below in parentheses, and ${ }^{*},{ }^{*},{ }^{* * *}$ reflect two-tailed significance levels at $0.1,0.05$, and 0.01 , respectively. 
Table 4

The predictive ability of managers' propensity to leak bad news privately

\begin{tabular}{|c|c|c|c|c|c|c|}
\hline & Future_Loss & Future_Loss & Future_AEarn & Future_dEarn & Future_Miss & Future_Miss \\
\hline Firm_Private_Warn & $\begin{array}{r}0.054 \\
(6.40)^{* * *}\end{array}$ & $\begin{array}{r}0.053 \\
(5.78)^{* * *}\end{array}$ & $\begin{array}{r}-0.006 \\
(-5.34)^{* * *}\end{array}$ & $\begin{array}{r}-0.007 \\
(-6.71)^{* * *}\end{array}$ & $\begin{array}{r}0.028 \\
(2.53)^{* *}\end{array}$ & $\begin{array}{r}0.051 \\
(3.91)^{* * *}\end{array}$ \\
\hline \multicolumn{7}{|l|}{ Firm controls: } \\
\hline \multirow[t]{2}{*}{$\overline{\text { Loss }}$} & 0.506 & 0.051 & 0.015 & 0.030 & 0.018 & -0.009 \\
\hline & $(14.39)^{* * *}$ & $(1.39)$ & $(6.63)^{* * *}$ & $(10.15)^{* * *}$ & $(1.35)$ & $(-0.62)$ \\
\hline \multirow[t]{2}{*}{$M V$} & -0.187 & -0.387 & 0.006 & 0.006 & -0.114 & 0.112 \\
\hline & $(-8.31) * * *$ & $(-8.06) * * *$ & $(6.56)^{* * *}$ & $(1.51)$ & $(-5.24) * * *$ & $(1.94)^{*}$ \\
\hline \multirow[t]{2}{*}{$M B$} & -0.030 & -0.126 & 0.002 & 0.009 & -0.064 & 0.003 \\
\hline & $(-1.44)$ & $(-5.86)^{* * *}$ & $(1.34)$ & $(3.59)^{* * *}$ & $(-4.40)^{* * *}$ & $(0.13)$ \\
\hline \multirow[t]{2}{*}{ Sales_Growth } & 0.026 & -0.039 & -0.004 & -0.002 & 0.014 & -0.003 \\
\hline & $(2.68)^{* *}$ & $(-4.55)^{* * *}$ & $(-3.22)^{* * *}$ & $(-1.57)$ & $(1.18)$ & $(-0.26)$ \\
\hline \multirow[t]{2}{*}{ Age } & -0.092 & -0.130 & 0.003 & 0.011 & 0.029 & -0.186 \\
\hline & $(-3.96)^{* * *}$ & $(-1.69)$ & $(2.48)^{* *}$ & $(1.83)^{*}$ & $(1.88)^{*}$ & $(-2.08)^{* *}$ \\
\hline \multirow[t]{2}{*}{ Public_Guidance } & & & & & -0.096 & 0.016 \\
\hline & & & & & $(-11.96)^{* * *}$ & $(1.02)$ \\
\hline \multirow[t]{2}{*}{$E S$} & & & & & -0.092 & -0.079 \\
\hline & & & & & $(-3.91)^{* * *}$ & $(-3.52)^{* * *}$ \\
\hline \multirow[t]{2}{*}{$M B E$} & & & & & -0.113 & 0.069 \\
\hline & & & & & $(-7.45)^{* * *}$ & $(3.71)^{* * *}$ \\
\hline \multirow[t]{2}{*}{$N$} & & & & & -0.018 & -0.064 \\
\hline & & & & & $(-1.12)$ & $(-2.02)^{*}$ \\
\hline \multirow[t]{2}{*}{ Inst_Hold } & & & & & -0.015 & 0.017 \\
\hline & & & & & $(-1.34)$ & $(0.63)$ \\
\hline Year-quarter fixed effects & YES & YES & YES & YES & YES & YES \\
\hline Firm fixed effects & NO & YES & NO & YES & NO & YES \\
\hline $\mathrm{n}$ & 12,618 & 12,618 & 12,618 & 12,618 & 12,618 & 12,618 \\
\hline Adjusted $R^{2}$ & $36.2 \%$ & $51.9 \%$ & $6.4 \%$ & $6.4 \%$ & $6.2 \%$ & $16.4 \%$ \\
\hline
\end{tabular}

Notes: This Table estimates the relation between managers' propensity to leak bad news to analysts and future bad news using linear probability models (estimated using OLS). Future bad news is (1) an indicator variable equal to 1 when a firm reports negative earnings at the quarter $q$ earnings release (Future_Loss), and 0 otherwise; (2) a continuous variable to account for firms' earnings decreases (Future_AEarn); and (3) an indicator variable equal to 1 when a firm misses quarter $q$ earnings expectations (Future_Miss), and 0 otherwise. Appendix A summarizes the variable definitions and constructions in detail. All continuous variables are ranked to quarterly deciles and subsequently transformed to a [-0.5,0.5] scale. I include year-quarter and firm fixed effects. Standard errors are adjusted for heteroskedasticity and clustered by firm and year-quarter. Coefficient estimates and t-statistics are presented below in parentheses, and ${ }^{*},{ }^{* *},{ }^{* * *}$ reflect two-tailed significance levels at $0.1,0.05$, and 0.01, respectively. 
Table 5

Expected litigation risk and managers' propensity to leak bad news privately

\begin{tabular}{|c|c|c|}
\hline & Firm_Private_Warn & Firm_Private_Warn \\
\hline Litigation_Risk & $\begin{array}{r}0.179 \\
(2.15)^{* *}\end{array}$ & $\begin{array}{r}0.299 \\
(3.70)^{* * *}\end{array}$ \\
\hline \multicolumn{3}{|l|}{ Firm and market controls: } \\
\hline$\overline{P u b l i c_{-} G u i d a n c e}$ & $\begin{array}{r}0.006 \\
(0.62)\end{array}$ & $\begin{array}{r}0.015 \\
(1.29)\end{array}$ \\
\hline$E S$ & $\begin{array}{r}-0.094 \\
(-6.41)^{* * *}\end{array}$ & $\begin{array}{r}-0.129 \\
(-7.23)^{* * *}\end{array}$ \\
\hline Loss & $\begin{array}{r}-0.008 \\
(-0.86)\end{array}$ & $\begin{array}{r}-0.019 \\
(-2.11)^{* *}\end{array}$ \\
\hline$M B E$ & $\begin{array}{r}-0.045 \\
(-4.54)^{* * *}\end{array}$ & $\begin{array}{r}-0.037 \\
(-3.26)^{* * *}\end{array}$ \\
\hline$M V$ & $\begin{array}{r}-0.027 \\
(-1.55)\end{array}$ & $\begin{array}{r}0.096 \\
(2.23)^{* *}\end{array}$ \\
\hline$M B$ & $\begin{array}{r}0.003 \\
(0.22)\end{array}$ & $\begin{array}{l}-0.015 \\
(-0.72)\end{array}$ \\
\hline Sales_Growth & $\begin{array}{r}-0.024 \\
(-1.96)^{*}\end{array}$ & $\begin{array}{l}-0.002 \\
(-0.17)\end{array}$ \\
\hline$N$ & $\begin{array}{r}0.032 \\
(1.73)^{*}\end{array}$ & $\begin{array}{r}0.003 \\
(0.12)\end{array}$ \\
\hline Inst_Hold & $\begin{array}{r}0.021 \\
(1.76)^{*}\end{array}$ & $\begin{array}{r}0.024 \\
(1.31)\end{array}$ \\
\hline Industry_Ret & $\begin{array}{l}-0.004 \\
(-0.33)\end{array}$ & $\begin{array}{r}0.001 \\
(0.10)\end{array}$ \\
\hline Market_Ret & $\begin{array}{r}0.013 \\
(0.87)\end{array}$ & $\begin{array}{l}-0.024 \\
(-1.13)\end{array}$ \\
\hline Litigation_Industry & $\begin{array}{r}-0.003 \\
(-0.33)\end{array}$ & \\
\hline Blue_State & $\begin{array}{r}0.022 \\
(2.67)^{* *}\end{array}$ & $\begin{array}{l}-0.020 \\
(-0.75)\end{array}$ \\
\hline Circuit fixed effects & YES & $\mathrm{NO}$ \\
\hline Year-quarter fixed effects & YES & YES \\
\hline Firm fixed effects & $\mathrm{NO}$ & YES \\
\hline $\mathrm{n}$ & 12,618 & 12,618 \\
\hline Adjusted $R^{2}$ & $3.6 \%$ & $13.5 \%$ \\
\hline
\end{tabular}

Notes: This Table estimates the relation between managers' perceived litigation risk and the propensity to leak bad news in private communications with analysts using OLS. The dependent variable is Firm_Private_Warn and the independent variable is Litigation_Risk. Appendix A summarizes the variable definitions and constructions in detail. All continuous variables are ranked to quarterly deciles and subsequently transformed to a $[-0.5,0.5]$ scale. I include circuit, year-quarter, and firm fixed effects. Standard errors are adjusted for heteroskedasticity and clustered by firm and year-quarter. Coefficient estimates and t-statistics are presented below in parentheses, and $*$, **, *** reflect two-tailed significance levels at $0.1,0.05$, and 0.01 , respectively. 
Table 6

Cross-sectional variation in firm size

\begin{tabular}{|c|c|c|c|c|}
\hline \multirow[t]{2}{*}{ Dependent variable: Firm_Private_Warn } & \multicolumn{4}{|c|}{$M V$} \\
\hline & small & large & small & large \\
\hline Litigation_Risk & $\begin{array}{r}0.143 \\
(0.90)\end{array}$ & $\begin{array}{r}0.225 \\
(3.10)^{* * *}\end{array}$ & $\begin{array}{r}0.250 \\
(1.98)^{*}\end{array}$ & $\begin{array}{r}0.307 \\
(3.58)^{* * *}\end{array}$ \\
\hline Difference in coefficients: & \multicolumn{2}{|c|}{$\begin{array}{c}-0.082 \\
(-2.13)^{* *}\end{array}$} & \multicolumn{2}{|c|}{$\begin{array}{c}0.057 \\
(-1.28)\end{array}$} \\
\hline Controls & YES & YES & YES & YES \\
\hline Circuit fixed effects & YES & YES & $\mathrm{NO}$ & $\mathrm{NO}$ \\
\hline Year-quarter fixed effects & YES & YES & YES & YES \\
\hline Firm fixed effects & NO & $\mathrm{NO}$ & YES & YES \\
\hline $\mathrm{n}$ & 6,309 & 6,309 & 6,309 & 6,309 \\
\hline Adjusted $R^{2}$ & $3.7 \%$ & $4.0 \%$ & $12.8 \%$ & $13.3 \%$ \\
\hline
\end{tabular}

Notes: This table estimates the relation between managers' perceived shareholder litigation risk and the propensity to leak bad news privately to analysts for small versus large firms using OLS. The dependent variable is Firm_Private_Warn and the independent variable is Litigation_Risk. The sample is partitioned in small and large firms using the median value of market capitalization as the cut-off point. Appendix A summarizes the variable definitions and constructions in detail. All continuous variables are ranked to quarterly deciles and subsequently transformed to a [-0.5,0.5] scale. I include firm, year-quarter, and circuit fixed effects. Standard errors are adjusted for heteroskedasticity and clustered by firm and year-quarter. Coefficient estimates and t-statistics are presented below in parentheses, and *, **, *** reflect two-tailed significance levels at $0.1,0.05$, and 0.01 , respectively. 